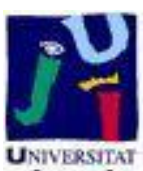

Título artículo / Títol article:

The gender gap in pay in company boards

Autores / Autors:

María Consuelo Pucheta- Martínez

Inmaculada Bel-Oms

Revista:

Industrial and Corporate Change

Versión / Versió:

Postprint

Cita bibliográfica / Cita bibliogràfica (ISO 690):

PUCHETA-MARTíNEZ, María Consuelo; BEL-OMS, Inmaculada. The gender gap in pay in company boards. Industrial and Corporate Change, 2014, p. dtu016.

url Repositori UJI:

http://hdl.handle.net/10234/145985 


\title{
The gender gap in pay in company boards
}

\author{
María Consuelo Pucheta-Martínez ${ }^{* \dagger \dagger}$ and Inmaculada Bel-Oms**
}

The aim of this study is to analyze whether a gender wage gap exists in the boards of directors (BD) of companies listed on the Madrid Stock Exchange from 2004 to 2011. We hypothesize that the percentage of female directors on a BD, the presence of female directors on the Nomination and Compensation Committee, the presence of wellqualified independent women directors on $\mathrm{BD}$, the sector, and the geographical region, have an effect on the gender wage gap. The results show that the percentage of female directors on a BD and the geographical region have no effect on the gender wage gap. On the other hand, the finding reports that women's presence on the Nomination and Compensation Committee increases the gender gap in pay, and it is reduced when there are independent female directors who have gained a degree on the $\mathrm{BD}$, and when the company operates in the finance and real estate services sector. In addition, the results also demonstrate that the seniority of the female directors decreases the gender gap in pay, while there is a rise when the companies are bigger and the size of the BD and the return on assets increase. These conclusions should encourage regulatory bodies to adopt forceful rules to mitigate the gender gap in pay.

JEL classification: M12, M0.

\section{Introduction}

Men's compensation has remained higher than women's for decades, resulting in a gender salary gap in which female pay has consistently been lower than that of their male counterparts. Gosling and Lemieux (2001) observed the ongoing existence of this gender pay gap in the labor markets of the most advanced industrialized countries. Meanwhile, Chu Ng (2004) and Cho (2007) showed that Chinese and Korean women also earned less than men. Jolliffe (2002) obtained similar results for

\footnotetext{
*María Consuelo Pucheta-Martínez, University Jaume I, Finance and Accounting, Campus del Riu Sec, s/n, Castellón, 12071, Spain. e-mail: pucheta@uji.es

${ }^{\star \star}$ Inmaculada Bel-Oms, University Jaume I, Finance and Accounting, Campus del Riu Sec, s/n, Castellón, 12071, Spain. e-mail: a1077067@uji.es

${ }^{\dagger}$ Main author for correspondence.
} 
Bulgaria. Chevalier (2007) found that women in the United Kingdom earned 20\% less than men, despite the country's long-standing anti-discrimination policies. Kulich et al. (2011) also examined the gender pay gap in senior posts at UK firms, finding that the salaries earned by male executives were higher than those of women at the same level of financial performance.

Previous studies focusing on analyzing gender gap in pay (Blau and Kahn, 1992; Kunze, 2005; Miyoshi, 2008; Vitaliano, 2009) show that it is caused by occupational segregation (Bayard et al., 1999; Palacio and Simón, 2006; De la Rica, 2007) and other factors that can be explained by human capital theory (García et al., 2001; Amarante and Espino, 2002; Rubery et al., 2005; Varela et al., 2010).

In this light, there is a clear need for further research into the factors underlying the gender gap in pay, an issue that has aroused considerable interest both in Spain (Hernández, 1995; Palacio and Simón, 2002; Simón, 2009) and internationally (Wood et al., 1993; Miyoshi, 2008; Papapetrou, 2008; Olsen et al., 2009; Vitaliano, 2009).

The aim of this study is to analyze whether there are differences in the pay earned by male and female directors serving on the boards of firms listed on the Madrid Stock Exchange, in the period 2004-2011, and if so, to examine the explanatory factors behind the gender gap in pay.

This study is particularly relevant in the Spanish context, as most analyses of the gender gap in pay refer to the English-speaking nations, or to Eastern European and some Asian countries. The contribution made by this study lies in its analysis of the gender gap in pay among the directors of firms listed on the Madrid Stock Exchange, as most existing studies (Simón, 2006; De la Rica, 2007; Del Rio et al, 2011) use data from the European Structure of Earnings Survey and as most of the previous empirical literature on the gender wage gap is based on the labor market in general, but very little empirical evidence for the groups of boards of directors (BD) in listed private companies exists. The results reported are therefore particularly important, as they confirm that there is a gender gap in pay at the top of the corporate hierarchy in Spain, due basically to the presence of women on the Nomination and Compensation Committee.

The structure of this article is as follows. This introduction is followed by a description of the institutional background in Spain. The third section describes the theoretical background and previous literature. The fourth section develops the hypotheses predicted. The fifth section describes the methodology and sample used in the study, and the sixth section shows the results obtained. In the seventh and final section, we discuss our conclusions and explain the limitations inherent in this study, at the same time pointing to possible future lines of research.

\section{Institutional background}

In Spain, between the 1970s and the 1990s many changes in legislation governing the treatment of men and women were introduced. There has been a general belief that 
one of the fundamental characteristics of the Spanish labor market was, and maybe is, the persistent and strong wage discrimination due to gender for similar jobs: men are clearly paid more than women. The equality principle was highlighted in Article 14 of the Spanish Constitution of 1978, which clearly prohibited discrimination on grounds of gender. The Workers' Statute Act of 1980 (amended several times since then) established in Article 28 a wage equality for work of equal value. Moreover, the third Plan for Equal Opportunities for Men and Women (1997-2000) recognized the persistence of unjustifiable wage inequalities for women already working. To palliate this unequal situation, a number of actions were taken under the Plan to provide women with real access to employment with full social and economic rights by encouraging structural changes and transformations that favored this purpose. In total and to date, there are four Plans for Equal Opportunities, the Activity Plans for Employment (with a special emphasis on gender equality) of 1998, and the EU Strategy Plan for Gender Equality of June 7, 2000. The Act 3/2007 of 22 March, "The Equality Law," for effective equality between women and men (LOIMH), implemented in 2007, in Article 5 also highlights that wage equality has to prevail between men and women. This regulation has had a positive impact mainly on discrimination in the public sector where today, one can hardly find a pay gap anymore in Spain (Ullibarri, 2003; Aláez et al., 2011).

Academic research into the pay earned by company directors in Spain was no easy task until only a few years ago, because the majority of listed firms did not publish information about board compensation. However, the Spanish Listed Companies Transparency Act (Law 26/2003), enacted in 2003 with the full backing of the National Securities Market Commission (CNMV), made it mandatory for listed firms to disclose details of directors' pay in their Annual Reports. As a consequence, data on the pay earned by Spanish directors have become available since this legislation entered the statute book. In 2011, the Sustainable Economy Act 2/2011 was passed to strengthen the application of EU Directive CRD3 for the financial sector and provide similar regulations for all listed companies. Under part of the Act, listed companies have to submit director and senior executive remuneration policy to a non-binding vote at the general meeting of shareholders.

The Spanish Corporate Governance System has been subject to significant reforms since the first publication in 1998 of what is known as the Olivencia Report, whose recommendations focused on the performance of firms and the publication of public information. It was followed in 2002 by the Law on Measures to Reform the Financial System (LMRFS), and in 2003 by the Law on Transparency of Listed Firms (LTLF). In 2003, the Aldama Report was also published and replaced the Olivencia Report and finally, in 2006 the Unified Code of Corporate Governance (CUBG) report or Conthe Code, was published, which unifies the Olivencia and Aldama Codes. The purpose of the CUBG (2006) was to improve business management and return transparency to the Spanish system. 
In this context, it is noteworthy that the continuous political and socioeconomic changes in Spain in recent years have increased gender diversity in BD. This raise was enhanced by the publication of the Conthe Code (CUBG, 2006), whose recommendations are intended to support female presence in decision-making bodies and eliminate possible discrimination. According to Gonzáléz Menéndez and Martínez González (2012), after this recommendation and the debate of the Draft Equality Law, most of the improvements in women's representation on boards occurred between 2005 and 2006. In addition, Act 3/2007 of 22 March, "The Equality Law," in Article 75 frames the regulation of the appointment of women and men in BDs in an equitable form for a period of 8 years since the law came into force. Spanish law followed the pattern of Norway, the first country in the world to establish a gender quota of $40 \%$ in boards, and this law also forced companies to reach a gender quota of $40 \%$ by 2015 . De Anca (2008) argues that this percentage is not a high target, given the high level of rotation among board members in Spanish listing firms. However, the progress made is still too slow to meet the government's 2015 target, and for this reason, González-Menéndez and Martínez-González (2012) recommend that stronger government sanctions, combined with more effective equality plans within companies, are required for the quota to be met.

In this sense, González-Menéndez and Martínez-González (2012) analyzed the Spanish Labour Force Survey and reported that the presence of women directors on the listed firms' corporate boards rose from $5.6 \%$ in 2002 to $10.40 \%$ in 2010 . In the same vein, De Anca (2008) examined 127 listed companies in 2006, including the Ibex 35 firms, and documented that only 5.1\% of the members of the Ibex 35 BDs were women directors, while the non-Ibex 35 companies had $6.7 \%$ women in BDs. The United Nations Report (2010) documented that the proportion of women increased from 6\% in 2007 to only 10\% on Spanish boards in 2009.

\section{Theoretical background and previous literature}

The salary structure of developed countries shows a gap in pay as a consequence of a higher influence in supply and the demand. For decades, the remunerations received by males have been, and are, greater than those of females, giving rise to a gender gap in pay. De Pablos (2001) documented that the salary received by women was smaller than men's and in $40 \%$ of the cases, the women's compensation was below the minimum salary. Amarante and Espino (2001, 2002) observed that the Uruguayan job market exhibited an important gender gap in pay. The two most relevant economic approaches that explain male-female wage differences in the companies are the human capital theory (Terjesen et al., 2009) and occupational segregation.

In this sense, previous studies that have analyzed gender gap in pay in developed countries (Blau and Kahn, 1992) have reported that most of the gender gap in pay is explained by human capital theory (García et al., 2001; Amarante and Espino, 2002; 
Varela et al., 2010) and occupational segregation theory (Bayard et al., 1999; Palacio and Simón, 2006; De la Rica, 2007).

Human capital theory posits that individuals invest in themselves, building up their own stock of knowledge, experience, and skills over the years (Becker, 1964). Human capital can be acquired either by years of educational attainment, or in the labor market, measured in terms of years of experience or seniority in a given job. For this reason, individuals can increase their productivity by learning work skills while they are on the job. However, women tend to invest less in human capital than men, mainly because they take on a greater share of domestic responsibilities and are less committed to their careers (Wood et al., 1993; Lips, 2003). Burke (2000) argues that board selectors held the assumption that women lack adequate human capital for board positions. This argument is empirically supported by Westphal and Milton (2000) and Singh et al. (2008), who reported that women directors are less likely to have top manager or focal director experience than men directors. In the same vein, Catalyst (1993) showed that CEOs were reluctant to appoint women as directors of BDs because they believe that females are unqualified. Carli (1990) and Heilman and Haynes (2005) documented that in a male-dominated context, female with work experience can neutralize negative opinions about women's performance, but they are presumed to be less competent than men. Thus, women begin their careers with less human capital than men and reap less compensation than men (Tharenou et al., 1994).

Hillman et al. (2002) showed that groups such as women can compensate for the effects of discrimination and subjective bias in selection procedures if they gain postgraduate qualifications. However, Hernández (1995) demonstrated that graduate men earned much more than women with the same university training. Similar evidence was reported by Zelechowski and Bilimoria (2004). García et al. (2001) showed that the gender gap in pay in Spain is higher for more trained women. Palacio and Simón (2002) and Ullibarri (2003) provide similar evidence. According to CES (Consejo Económico and Social, 2011), the gender gap in pay was exhibited at all training levels and it was greater when women were more trained. Contrary to this evidence, Gardín and Del Río (2009), Gonzalo and Pons (2001), and Ullibarri (2003) reported that between graduate men and women, there was not a gender gap in pay, but it was exhibited among women with elementary education.

Singh et al. (2008) showed that women had minor board experience but not less business experience than men. Studies such as De la Rica and Ugidos (1995) and Hernández (1995) demonstrated that women obtained a higher salary as they gained more experience in the company, and therefore, the gender gap in pay was reduced. In addition, Hernández (1995) demonstrated that when a woman's work contract lasted at least 2 years, their salary was increased, while that of men did not. Aláez and Ullibarri (1999) analyzed whether all Spanish regions exhibited a gender gap in pay and reported that women's experience was less than men's experience in all regions. Moreover, the authors demonstrated that the difference in experience between males 
and females was caused because women retired from active working life in order to take care of their children, which is one of the most important factors explaining the gender gap in pay. Simón et al. (2005) documented that the average salary earned by women was similar to men's salary when both had less experience in their jobs. According to Ortega (2007), experience was a key factor in establishing the pay of males and females.

Regarding women's seniority, it is expected that as women have more seniority, the gender gap exhibited in pay is smaller. The reason for the low seniority of women is the tardy incorporation of women into the labor market and their commitment to family life. In this sense, De la Rica and Ugidos (1995) showed that men with more seniority earned much more than women. The authors also reported that when women had the same education and seniority as men, the reduction of the gender gap in pay is $50 \%$. According to CES (2011), the gender gap in pay between males and females was higher as the seniority between them increased.

The occupational segregation approach excludes women from certain kinds of work, so that they tend to be concentrated in low-paid occupations (Dolado et al., 2004; Leaker, 2008; Olsen et al., 2009). Segregation can arise as the result of employer discrimination in hiring and promotion, or from human capital differences in education levels. In addition, occupational segregation can be divided between horizontal and vertical: the first analyses how men and women are distributed according to their occupation, and the second examines the distribution of male and female according to the hierarchical level within the organisation. The existence of a gender gap in pay in some occupations may be due to women being discouraged from entering high-wage occupations by discriminatory barriers. Jurajda (2003) demonstrated that the segregation of women in low-paying occupations was one third of the total wage gap. Simón (2006) reported that occupational segregation was a key factor in the gender gap in pay.

Authors such as Groshen (1991), Johnson and Solon (1986), and MacPherson and Hirsch (1995), among others, documented that men had higher wages than women, as women were employed in jobs where average remuneration was lower. Palacio and Simón (2002) concluded that the gender gap in pay in most of the cases is due to the way men and women are distributed within the labor market, as women are concentrated in jobs with low salaries. In the same vein, previous studies (Bayard et al., 1999; De la Rica, 2003) showed that women earned less than men because females were concentrated in low-paid occupations. Bell (2005) demonstrated that executive women with the same education and occupation earned less than executive men. Simón et al. (2005) concluded that the segregation of women increased in low-paid occupations and in those jobs where there were a high number of women. Ortega (2007) reported that the higher the occupational segregation, the higher the gender gap in pay. Thus, in those jobs with a high concentration of men, the gender gap in pay exhibited will be higher. Aláez and Ullibarri (1999) showed that women earned $19 \%$ less than men when both occupied the same job and had the same education. 
Bell (2005), Bird et al. (2007), and Castaño et al. (2008) demonstrated that of men and women directors, females earned less than males. Tenjo et al. (2005) analyzed the gender gap in pay in six Latin American countries and reported that the gender gap in pay per hour was reduced in Argentina, Brazil, Colombia, Honduras, and Uruguay, but in Costa Rica it considerably increased. In addition, they demonstrated that in Argentina, Colombia, and Honduras, the average wage per hour of women was higher than of men, except for housekeepers. Palacio and Simón (2006) showed that in the period 1995-2002, men earned higher salaries than women in the same hierarchical level and occupation, while Bird et al. (2007) documented that female accountants earned \$24 per hour less than male accountants. In the same sense, Castaño et al. (2008) revealed that executive women received $42 \%$ less of the wage than men. Porto et al. (2010) demonstrated that women directors earned 16.5\% less than male directors, and the gender gap in pay was lower when the hierarchical level was lower.

\section{Hypotheses development}

\subsection{Board membership: percentage of female directors on the board and presence of women on the Nomination and Compensation Committee}

Although women were scarcely represented on company boards until comparatively recently, their numbers have risen over the last decade or so, as they have become progressively better qualified. Mateos et al. (2007) found that only $6.61 \%$ of directors in the 1085 largest Spanish firms were women. Meanwhile, statistics published by the Spanish National Institute of Statistics (INE, 2012) show that women made up 10.3\% of directors in IBEX 35 companies, which is still low but nonetheless a considerable improvement-in 2005 less than $2 \%$ were women.

The percentage of female directors on $\mathrm{BD}$ may be an important factor for the supervision and control of the board's activities (Adams and Ferreira, 2009; Schwartz-Ziv, 2011). In this sense, research has found that women on boards have an important influence on firm performance (Adler, 2001; Adam and Ferreira, 2003; Carter et al., 2003; Catalyst, 2004; Farrel and Hersh, 2005; Krishnan and Park, 2005; Shrader et al., 2007; Campbell and Mínguez, 2008), financial reporting quality or fostering good corporate practice (Rogelberg and Rumery, 1996; Burgess and Tharenou, 2002), and dividend policy (Van Pelt, 2013; Wellalage et al., 2012), among others. Given the importance of women on boards in allocating capital to corporations, as well as their role in firm governance, an understanding of how their presence in boards affects the gender pay gap is undoubtedly needed.

Most studies that focus on wage disparity between male and female report that men earn significantly more than women, although some researchers argue that men and women receive similar compensation at management levels (Bowlin and Renne, 2008). 
Blau and Khan (2001) demonstrated that the implementation of a gender quota in BDs could develop egalitarian wage structures, and reduce the gender gap in pay. Bilimoria (2006) found a positive association between female corporate board members and women among the top corporate earners, exhibiting a smaller gender gap in pay. Terjesen and Singh (2008) show that boards with a higher representation of women are more likely to have women in senior management and smaller gender pay gaps. Smith et al. (2011) revealed that for the small and select group of CEOs the gender compensation gap decreased slightly. Jacobs (1992) demonstrated a narrowing of the gender pay gap among directors that is correlated with a substantial rise in the number of female directors. In the same vein, Cohen and Huffman (2007) demonstrated that as the representation of female directors increased, the gender wage gap narrowed. According to Jordan et al. (2007), for women who have reached a seat on the board, no gender pay gap exists, as females are paid virtually the same as their male counterparts.

Fondas and Sassalos (2000) indicated that women tend to have higher expectations regarding their responsibilities as directors, which may induce them to expend more effort on their tasks. Similarly, Huse and Solberg (2006) showed that women on corporate boards are better prepared for board meetings than men; thus, female representation may improve board behavior and effectiveness. According to Ittonen et al. (2010), gender diversity may improve the efficiency of corporate boards simply because female directors, in general, are presumably highly competent and hardworking. In this sense, Ye et al. (2010) provide evidence that companies with a higher proportion of women directors perform better than those without gender diversity, and Nielsen and Huse (2010) illustrated that women's presence on a BD reduces conflicts between the members of the board, thus promoting best practices in the company. Thus, we presume that female directors may improve the monitoring activities of the $\mathrm{BD}$ and as a result, it is more likely that they can narrow the gender gap in pay.

Hence, based on the arguments and evidence presented above, we hypothesize that a higher percentage of women directors on boards will decrease the gender wage gap:

Hypothesis 1: Firms with a greater percentage of female directors on their boards will 30 be more likely to have a smaller gender pay gap among directors of the Board

On the other hand, the pay of directors on the board can be a bone of contention between managers and shareholders. The Spanish Unified Code of Good Governance (CUBG, 2006) recommended the inclusion of women on a board and its committees, assigning responsibility for selection processes to the Nomination Committee, which should seek to recruit candidates with the required professional profile while avoiding gender discrimination at all times. Meanwhile, responsibility for proposing directors' and executives' pay lies with the Compensation Committee.

According to Klein (2003), Compensation Committees should not confine themselves to moderating directors' pay, but should also take responsibility for the design of remuneration structures capable of incentivizing behavior in line with 
shareholders' interests and rewarding enhanced business performance. Conyon (1997), Klein (1998), Kose and Lemma (1998) and Among others, Arrondo et al. (2008) found that the presence of a Nomination and Compensation Committee did in fact rein in directors' pay. Shin (2012) shows that the gender gap in executive pay is smaller when a greater percentage of women sit on the Compensation Committee of the board, which is the group responsible for setting executive compensation.

As shown above, the previous evidence about the relationship between the presence of women directors on the Compensation Committee and the gender wage gap is scarce. However, we predict that the presence of women on the Nomination and Compensation Committee will increase the gender pay gap among board members for two reasons. The first reason is because women are less likely to sit on Compensation Committees than men (Adams and Ferreira, 2009), and this means that women directors have less involvement in setting boards members pay and not as much influence over the design of board director's compensation as their male counterparts, and consequently, they cannot put pressure on their male counterparts in order to get equal salaries for all board members. Secondly, according to Kulich et al. (2011), members of the Compensation Committee, mainly men, may feel the need to offer male directors higher compensation compared with that offered to female directors, in order to attract and retain male directors on the board, as male directors on Compensation Committees perceive female leaders to be less instrumental in achieving particular corporate outcomes.

In light of the above, we propose the following hypotheses:

Hypothesis 2: Firms with the presence of women on the Nomination and Compensation Committee will be more likely to have a greater gender pay gap among directors of the Board

\subsection{Educational level of female independent directors}

As women have joined the labor market in increasing numbers in recent decades, they have become progressively better qualified, allowing them to rise above their historical situation, which confined them largely to basic education and domestic concerns. Education, a human capital variable that is positively related to the ability of the manager, has a clear effect on pay (Coelho et al., 2010). Education can potentially increase earning power, and women are specifically encouraged to use education where possible to increase their earning potential (Lips, 2008). If educational qualifications are important determinants of performance in a company, and if females have higher levels of qualifications (Blau and Kahn, 2007), then women will earn higher wages (Arulampalam et al., 2007). As a consequence, the gender wage gap can be reduced.

In this sense, Mukhopadhayay (2001) observed that rising female education in Singapore caused a reduction in the gender pay gap. Similarly, the education received by Canadian women in the period 1986-1991 was the determining factor in narrowing the gap between male and female compensation (Christie and Shannon, 2001). 
Ullibarri (2003) Gonzalo and Pons (2001) and Gardín and Del Río (2009) reported that between graduate men and women, there was no gender gap in pay, but it was seen for women with elementary education. Aláez and Ullibarri (1999) analyzed the gender gap in pay in the different regions of Spain, finding the largest gender pay gaps were in those regions where both men and women were least educated and the education of women was similar to that of men (Murcia and Castile-La Mancha). Along the same lines, the Spanish Economic and Social Council (CES, 2011), Del Río et al. (2011), and Simón et al. (2008), among others, found that the gender-based salary gap narrows with the level of education. Coelho et al. (2010) also reported that the gender wage gap is narrower when women have more advanced degrees. Similar evidence was reported by other authors (Blau and Kahn, 2007; Chevalier, 2007; Izquierdo and Lacuesta, 2007), who showed that improvements in the level of women's qualifications explain a substantial portion of the narrowing of the gender pay gap.

Contrary to this evidence, García et al. (2001), Palacio and Simón (2002), Jurajda (2003), Mirta (2003), De la Rica et al. (2005), Simón et al. (2005), Plantenga and Remedy (2006), Böheim et al. (2007) and Ortega (2007) reported that the gender pay gap is greater among better qualified workers, while Simón (2006) found that the gap in pay between the best educated male and female workers was greater in Spain than in any other European country, except Ireland, although the gap was smaller among less well-qualified workers. Palacio and Simón (2002) and Cho (2007) reported that male-female pay inequality was greater in both Spain and Korea not only when the women concerned lacked educational qualifications, but also among female graduates. Hernández (1995), Lauer (2000) and De la Rica (2007) showed that men earned higher pay than women even when they were educated to the same level.

Our aim was to investigate the qualifications of all women holding board level office in listed Spanish firms. However, published Corporate Governance reports only include information on the qualifications of independent directors, and we shall therefore confine ourselves to examining the qualifications of these women. Human capital theory argues that one of the explanations for the gender wage gap is the difference in human capital among individuals, such as education (Lazear and Rosen, 1990; Crossley et al., 1994; Mincer and Polachek, 1994). Tharenou et al. (1994) argue that females, compared with males, have traditionally made fewer investments in education and work experience and this is reflected in lower pay and promotion. Thus, based on this argument and previous evidence, we posit that the presence of qualified women directors on the $\mathrm{BD}$ will diminish the gender gap in pay, as qualified female directors may receive top salaries and positions as often as their male counterparts. Consequently, well-qualified female independent directors will help narrow the gender pay gap. Hence, we posit the following hypothesis:

Hypothesis 3: Firms with a presence of well-qualified female independent directors on boards will be more likely to have a smaller gender pay gap among directors of the 40 Board 


\subsection{Firm sector}

The sector in which a firm operates is an important factor, as the businesses in which they engage may influence gender gap in pay (Jurajda and Harmgart, 2007). Kulich et al. (2011) examined UK listed firms from 1998 to 2004 and demonstrated that there was a significant gender pay gap in executive positions when controlling for industry. Skalpe (2007) analyzed 1.866 private firms from the tourism and manufacturing industries from 1999 to 2001 and showed that female CEOs were wagediscriminated in both sectors. Nonetheless, the gender gap in pay was greater in tourism companies because the female CEOs in this industry were employed in smaller firms than is the case in manufacturing. Bertrand and Hallock (2001) also found a considerable gender wage gap in top management, and most of the gender pay differential was explained by industry or occupational levels, among other reasons. Meanwhile, Renner et al. (2002) demonstrated that variations in annual compensation between female and male executive directors can be explained by the industrial sector.

Contrary to this evidence, Vieito and Khan (2012) reported that there was no gender wage gap between male and female executive directors of BD of technology firms. Similar evidence was reported by Smith et al. (2011) and Holst and Busch (2009), who after controlling for industry and other characteristics, showed that a gender wage gap among directors did not exist.

The existing evidence is not conclusive and therefore, it is not evident how the sector in which the company operates can explain the gender gap in pay that may exist between male and female directors of the BD. Consequently, we propose the following hypothesis:

Hypothesis 4: The sector in which the company operates can increase or narrow the gender wage gap among directors of the Board

\subsection{Geographical region}

The compensation of male and female board members may vary depending on the geographical region of the company (Lago, 2002), mainly due to differences in the cost of living and non-monetary conditions of employment. Towns and cities are often more expensive than rural areas (Skalpe, 2007). Gomez-Mejia et al. (1987) proposed that geographical location might affect the executives' compensation level.

In this vein, Holst (2006) examined 80,000 German firms and demonstrated that women and men directors on the board both earned significantly less in East Germany (former GDR) than in West Germany, but the regional difference was larger for men. This result suggests that firm location influences the gender wage gap. In contrast with this finding, Skalpe (2007) examined Norwegian tourism and manufacturing companies and showed that the urban location of the company did not appear to influence the gender wage gap among executive directors. 
Aláez and Ullibarri (1999) examined male-female compensation discrimination in the Spanish regions, finding the widest gender pay gaps in Catalonia and Murcia and the smallest in the Balearic Islands and La Rioja. Meanwhile, Palacio and Simón (2002) found a significant gender pay gap in large firms located in Catalonia and Madrid. Finally, the report of the Spanish National Statistics Institute entitled INE: Women and Men of Spain (2012) lists the Autonomous Communities with the smallest gender pay gaps as the Canary Islands (13.6\%), Extremadura (15.8\%), the Balearic Islands (20.2\%), and Castile-La Mancha (21.9\%). The gap was widest in Asturias (29.8\%) and Aragon (31.1\%).

Internationally, Chu $\mathrm{Ng}$ (2004) studied data obtained from the Chinese Office of Statistics for the period 1988-1992, arguing that the gender pay gap was widest in western China, away from the coast, where economic progress has been slower. In contrast, they showed that rapid growth along China's eastern seaboard and in the center of the country reduced the pay gap. Leaker (2008) reported that women's compensation was lower throughout the United Kingdom, and that the gender pay gap was widest in the South-West and South-East of the country.

Like the firm sector variable, it is not easy to predict a priori whether a firm's geographical region will increase or decrease male-female compensation differences between directors, because the gender pay gap depends on the specific location of each firm, as the existing literature shows. In this light, we propose the following hypothesis:

Hypothesis 5: The geographical region in which the company is situated can increase or narrow the gender wage gap among directors of the Board

\section{Methodology and sample}

\subsection{Methodology}

We shall use the following model to empirically test the hypotheses proposed above:

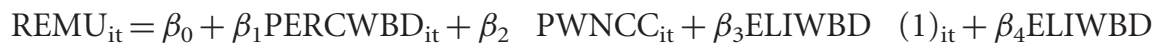
$(2)_{\text {it }}+\beta_{5}$ FSEC (1) ${ }_{\text {it }}+\beta_{6}$ FSEC (2) ${ }_{\text {it }}+\beta_{7}$ FSEC (3) ${ }_{\text {it }+} \beta_{8}$ FSEC (4) ${ }_{\text {it }+} \beta_{9}$ FSEC (5) it $+\beta_{10}$ GREG (1) $)_{\text {it }}+\beta_{11}$ GREG (2) $)_{\text {it }}+\beta_{12}$ GREG (3) $)_{\text {it }}+\beta_{13}$ GREG $(4)_{\text {it }}+\beta_{14}$ $\operatorname{GREG}(5)_{\mathrm{it}}+\beta_{15} \operatorname{SEN}(1){ }_{\text {it }}+\beta_{16} \operatorname{SEN}(2)_{\mathrm{it}}+\beta_{17} \operatorname{SEN}(3)_{\text {it }}+\beta_{18}$ FIRMSIZE $_{\mathrm{it}}+\beta_{19}$ $\mathrm{PROD}_{\mathrm{it}}+\beta_{20} \mathrm{ROA}_{\mathrm{it}}+\beta_{21} \mathrm{BDSIZE}_{\mathrm{it}}+\sum_{\mathrm{j}} \alpha \mathrm{j} \mathrm{FIRM}_{\mathrm{j}}+\mu_{\mathrm{it}}$

Where the dependent variable, $R E M U_{i t}$, is calculated as the logarithm of the difference between the compensation of male and female directors in firms listed on the Madrid Stock Exchange. ${ }^{1}$ The calculation of this variable is based on annual rather than hourly pay, because that is how the data are presented in the Annual

\footnotetext{
${ }^{1}$ The logarithm of the difference between mean values of male and female directors' compensation of firms listed on the Madrid Stock Exchange has been also used as a dependent variable. The mean
} 
Corporate Governance Reports published by the firms analyzed. The remuneration considered comprises fixed and variable pay, as well as allowances. The variables used in the model and the expected signs of each are shown in Table 1.

\subsection{Independent and control variables}

\subsubsection{Independent variables}

\section{Percentage of female directors on the board}

This variable is denoted by "PERCWBD" and it is calculated as the ratio between the total number of female directors on the board and the total number of directors on the board. It is expected to be negative, as we predict that the gender pay gap between directors will narrow given an increase in the percentage of female board members.

\section{Presence of women on the Nomination and Compensation Committee}

Female membership of the Nomination and Compensation Committee is approximated by the variable "PWNCC," defined as a dummy variable which takes a value of 1 if the members of the committee include any women and 0 , otherwise. This variable is expected to be positive, as we predict that the presence of women on the Nomination and Compensation Committee will increase the gender pay gap between directors.

\section{Educational level of female independent directors in the Board of Directors}

"ELIWBD" represents the educational level of female independent directors on the board. As explained above, we have only considered the qualifications of female independent directors because this is the only data regarding the education of board members contained in Corporate Governance Reports. "ELIWBD” is calculated as a categorical variable, and we have therefore created C-1 dichotomous variables. Having created the dichotomous variables, the next step is to establish the reference category we wish to compare with the other categories. We have classified educational level as follows: ELIWBD $(0)=$ no details of female independent director qualifications in the Corporate Governance Report; ELIWBD (1) = BA/BSc. degree; and ELIWBD $(2)=$ Phd. The reference category is ELIWBD (0). The variable is expected to be negative, as the gender pay gap between directors will be narrower, the better qualified the female independents serving on a firm's board.

\section{Firm Sector}

The business sector variable was defined on the basis of the Madrid Stock Exchange classification: FSEC (1)= Oil and energy; FSEC (2)=Commodities, industry, and construction; FSEC (3)=Consumer goods; FSEC (4)=Consumer services; FSEC

value of compensation is calculated as the ratio between the total remuneration of the director and the total number of directors of the BD. The results, not provided, are unaffected. 
Table 1 Independent and control variables

\begin{tabular}{|c|c|c|c|}
\hline Variable & Label & Measurement & $\begin{array}{l}\text { Expected } \\
\text { sign }\end{array}$ \\
\hline \multicolumn{4}{|l|}{ Independent variables } \\
\hline $\begin{array}{l}\text { Percentage of women in } \\
\text { the board of directors }\end{array}$ & PERCWBD & $\begin{array}{l}\text { Total number of women on the board of } \\
\text { directors/total number of members on the } \\
\text { board of directors }\end{array}$ & - \\
\hline $\begin{array}{l}\text { Presence of women on the } \\
\text { Nomination and } \\
\text { Compensation Committee }\end{array}$ & PWNCC & $\begin{array}{l}\text { Dummy Value }(1=\text { Presence of women on the } \\
\text { Nomination and Compensation Committee; } \\
0=\text { Otherwise) }\end{array}$ & + \\
\hline $\begin{array}{l}\text { Educational level of } \\
\text { independent women in } \\
\text { the board of directors }\end{array}$ & ELIWBD (1) & $\begin{array}{l}\text { Dummy Value }(1=\text { Independent women } \\
\text { graduate; } 0=\text { Otherwise) }\end{array}$ & - \\
\hline $\begin{array}{l}\text { Educational level of } \\
\text { independent women in } \\
\text { the board of directors }\end{array}$ & ELIWBD (2) & $\begin{array}{l}\text { Dummy Value ( } 1=\text { Independent women PhD; } \\
0=\text { Otherwise) }\end{array}$ & - \\
\hline Firm sector & FSEC (1) & $\begin{array}{l}\text { Dummy Value ( } 1=\text { Oil and energy; } \\
0=\text { Otherwise) }\end{array}$ & $+/-$ \\
\hline Firm sector & FSEC (2) & $\begin{array}{l}\text { Dummy Value ( } 1=\text { Commodities, industry } \\
\text { and construction; } 0=\text { Otherwise) }\end{array}$ & $+/-$ \\
\hline Firm sector & FSEC (3) & $\begin{array}{l}\text { Dummy Value }(1=\text { Consumer goods; } \\
0=\text { Otherwise) }\end{array}$ & $+/-$ \\
\hline Firm sector & FSEC (4) & $\begin{array}{l}\text { Dummy Value }(1=\text { Consumer Services; } \\
0=\text { Otherwise) }\end{array}$ & $+/-$ \\
\hline Firm sector & FSEC (5) & $\begin{array}{l}\text { Dummy Value }(1=\text { Finance and property ser- } \\
\text { vice; } 0=\text { Otherwise) }\end{array}$ & $+/-$ \\
\hline Geographical region & GREG (1) & $\begin{array}{l}\text { Dummy Value }(1=\text { Northwest; } \\
0=\text { Otherwise) }\end{array}$ & $+/-$ \\
\hline Geographical region & GREG (2) & Dummy Value ( $1=$ Northeast; $0=$ Otherwise $)$ & $+/-$ \\
\hline Geographical region & GREG (3) & Dummy Value ( $1=$ Madrid; $0=$ Otherwise) & $+/-$ \\
\hline Geographical region & GREG (4) & Dummy Value ( $1=$ Centre; $0=$ Otherwise) & $+/-$ \\
\hline Geographical region & GREG (5) & Dummy Value ( $1=$ East; $0=$ Otherwise $)$ & $+/-$ \\
\hline \multicolumn{4}{|l|}{ Control variables } \\
\hline Seniority & SEN (1) & $\begin{array}{l}\text { Dummy Value }(1=\text { one year of seniority; } \\
0=\text { Otherwise) }\end{array}$ & - \\
\hline Seniority & SEN (2) & $\begin{array}{l}\text { Dummy Value ( } 1=\text { From two to four years of } \\
\text { seniority; } 0=\text { Otherwise) }\end{array}$ & - \\
\hline Seniority & SEN (3) & $\begin{array}{l}\text { Dummy Value ( } 1=\text { From five to eight years of } \\
\text { seniority; } 0=\text { Otherwise) }\end{array}$ & - \\
\hline Company size & FIRMSIZE & Log of total assets (in thousands of Euros) & + \\
\hline Productivity & PROD & Log (Turnover/ Number of employees) & + \\
\hline Return on Assets & ROA & Ordinary result/Average of total assets & + \\
\hline Size of the board & BDSIZE & $\begin{array}{l}\text { Total number of directors on the board of } \\
\text { directors }\end{array}$ & + \\
\hline
\end{tabular}


(5) = Financial services and property (excluding banks, which do not form part of the sample); and FSEC (6)=Technology and telecommunications. The value of the dummy variables is 1 if the company belongs to the sector in question and 0 otherwise. The reference category is FSEC (6). We expect this variable to be both positive and negative, as the salary gap may increase or decrease depending on the sector to which the firm belongs. The sector classification is shown in Table 2.

\section{Geographical region}

This variable is denoted by "GREG" and is based on the Autonomous Community (political region) in which the firm is located. Following Arrazola and Hevia (2009) and Pagán (2007), we have grouped the Autonomous Communities into seven macro-regions: Northwest, Northeast, Madrid, Central Spain, East, South, and Canary Islands. Although we initially intended to follow this classification, we found that none of the firms in the sample is in fact registered in the Canary Islands. As a result, we included the Canaries in the South, leaving only six regions. The classification of the six regions is therefore as follows: GREG (1)=Northwest; GREG (2) = Northeast; GREG (3)= Madrid; GREG (4)= Center; GREG (5)= East, and GREG (6) = South and Canary Islands. Table 3 details the six regions and the Autonomous Communities that form each. Like educational level and sector, region is a categorical variable. The reference category is GREG (6). This variable is again expected to be both positive and negative, as the salary gap may widen or narrow depending on the firm's geographical region.

\subsubsection{Control variables}

To test the model, we have included five control variables that could influence malefemale differences in compensation.

\section{Seniority of women on the board}

The first control variable considered is seniority, which is a key factor in the promotion of both men and women. It is therefore to be expected that a longer period of service in a firm will open the way to positions of responsibility and will also reduce the gender pay gap. Aláez and Ullibarri (1999) claim that the gender pay gap is greater in those regions where women's job seniority is shorter than men's. Barceinas et al. (2000), Lauer (2000), Mirta (2003), Simón (2006), and Simón (2009) found that women were likely to earn less than men where they had spent less time in their jobs. Likewise, De la Rica and Ugidos (1995), Monk and Turner (2004), Miyoshi (2008), and Olsen et al. (2009) concluded that men with longer service with their firms earned higher salaries. According to CES (2011), the gender pay gap between men and women widened considerably as their job seniority increased.

This categorical variable is denoted by "SEN." The classification is as follows: SEN $(0)=$ No period of seniority; SEN (1) = 1 year of seniority; SEN (2) = 2-4 years of 
Table 2 Classification of the sector

\begin{tabular}{|c|c|c|}
\hline \multirow{3}{*}{ SECTOR 1} & \multirow{3}{*}{ Oil and Energy } & 1. Oil \\
\hline & & 2. Energy and gas \\
\hline & & 3. Renewable energy \\
\hline \multirow{7}{*}{ SECTOR 2} & \multirow{7}{*}{ Commodities, industry, and construction } & 1. Minerals, metals, and transportation \\
\hline & & 2. Production equipment goods \\
\hline & & 3. Construction \\
\hline & & 4. Materials of construction \\
\hline & & 5. Chemical industry \\
\hline & & 6. Engineering and others \\
\hline & & 7. Aerospatiale \\
\hline \multirow{5}{*}{ SECTOR 3} & \multirow{5}{*}{ Consumer goods } & 1. Foods and drinks \\
\hline & & 2. Textile, dress, and shoes \\
\hline & & 3. Paper and graph arts \\
\hline & & 4. Pharmaceutical products and \\
\hline & & 5. Others consumers goods \\
\hline \multirow{6}{*}{ SECTOR 4} & \multirow{6}{*}{ Consumer services } & 1. Leisure, tourism, and hotel industry \\
\hline & & 2. Retailer trade \\
\hline & & 3. Media and advertising \\
\hline & & 4. Transport and distribution \\
\hline & & 5. Motorway and car park \\
\hline & & 6. Other services \\
\hline \multirow{6}{*}{ SECTOR 5} & \multirow{6}{*}{ Financial and property services } & 1. Bank and savings bank \\
\hline & & 2. Insurance \\
\hline & & 3. Portfolio and holding \\
\hline & & 4. SICAV \\
\hline & & 5. Real estate and others \\
\hline & & 6. Investment services \\
\hline \multirow{2}{*}{ SECTOR 6} & \multirow{2}{*}{ Technology and telecommunications } & 1. Telecommunications and others \\
\hline & & 2. Electronic and software \\
\hline
\end{tabular}

Table 3 Classification of the regions

\begin{tabular}{lll}
\hline Label & Area & Region \\
\hline GREG (1) & NORTHWEST & Galicia, Asturias, Cantabria \\
GREG (2) & NORTHEAST & País Vasco, Navarra, La Rioja y Aragón \\
GREG (3) & MADRID & Madrid \\
GREG (4) & CENTER & Castilla y León, Castilla la Mancha, Extremadura \\
GREG (5) & EAST & Cataluña, Comunidad Valenciana, Baleares \\
GREG (6) & SOUTH AND THE CANARY ISLANDS & Andalucía, Murcia, Ceuta, Melilla y Canarias \\
& &
\end{tabular}


seniority, and SEN (3) = 5-8 years of seniority. These variables take a value of 1 if female directors have the seniority indicated in the year considered and 0 , otherwise. The reference category taken to measure this categorical variable is SEN (0). We expect this variable to be negative. Hence, the longer a female director's seniority, the greater the reduction in the gender pay gap should be because the inclusion of experienced female directors on the board will push firms to comply more strictly with the gender equality legislation applicable to listed companies, and to eliminate male-female compensation differences.

\section{Firm size}

The size of the firm is also used as a control variable. Size is sometimes associated with a firm's business and financial characteristics, and it may therefore affect the gender pay gap. In this regard, Palacio and Simón (2002), Mirta (2003), Monk and Turner (2004), Pagán (2007) and Gardín and del Río (2009) showed that malefemale compensation differences were greater in large firms. Meanwhile, Gartner and Stephan (2004) concluded from an analysis of German companies that the gender pay gap grew wider, the larger the firm. Bell (2005) found that firm size and the disproportionately small number of female CEOs and company chairwomen were responsible for between 50 and 60\% of the gender pay gap. Heinze and Wolf (2010) also reported that the gender pay gap was wider in large German concerns, at the same time showing that male-female compensation differences were smaller in family firms. However, CES (2011) observed that male-female compensation differences were greater in Spanish SMEs with less than 10 employees. Similarly, Arrondo et al. (2008), Fernández Méndez et al. (2011), and Pucheta and Narro (2014) showed that a firm's size had a positive and significant influence on directors' pay. The variable is denoted by "FIRMSIZE" and is calculated as the logarithm of the firm's total assets. It is expected to be positive, as the gender pay gap among directors will be greater the larger the firm.

\section{Employee productivity}

The third control variable used to study the gender pay gap is employee productivity, which is denoted by "PROD" and is measured as the logarithm of the ratio of turnover to the firm's total number of employees, following Mateos et al. (2007). The flexibility and effectiveness of the labor market are essential to ensure that employees are assigned efficiently in the economy. Furthermore, firms need to draw on their employees' skills and training, and to incentivise performance, taking into account compensation equality between men and women. Examining a sample of companies in Mexico, Blomström (1985) showed that foreign firms were 79\% more efficient in their use of labor than their local peers due to factors such as training and the level of business concentration. Haltiwanger et al. (2007), Iranzo et al. (2006), and Newell and Relly (1996) all found that the personal characteristics of employees contributed significantly to explaining differences in productivity between firms. 
Meanwhile, Doménech (2008) revealed that firms whose employees were better trained were more productive. Guisán and Aguayo (2008) observed that productivity per employee was very low in Spain compared with other developed economies. Fan and Lui (2003) showed that the gender pay gap narrowed when the productivity of female employees in Hong Kong rose compared with their productivity as perceived by their male peers. Likewise, Monk and Turner (2004) found that male-female compensation differences decreased as employee productivity increased in South Korea.

This variable is expected to be positive, as we understand that employee productivity gains will raise directors' pay, given their responsibility for management. However, the gender pay gap will also widen, as the positions of greatest responsibility on company boards are usually occupied by men, who are therefore likely to be credited with successfully raising productivity.

\section{Return on assets}

Return on assets is another of the control variables considered, reflecting the firm's profitability in terms of income generated for every euro invested in assets. This variable is denoted by "ROA" and is calculated as the ratio of ordinary income to average total assets, although some authors, such as Manzaque et al. (2008), calculate it as the ratio of the operating margin to total assets. We expect this variable to be positive, because an increase in a firm's profitability will result in higher compensation for directors and a proportional widening of the gender pay gap. Arrondo et al. (2008) and Fernández Méndez et al. (2011) show that the return on assets has a positive and significant effect on directors' pay.

\section{Board size}

The last of the control variables considered is the size of the board, as the number of directors may affect control and management of the firm. The board is the body responsible for safeguarding the interests of the shareholders and controlling the management team (Salas, 2002). The Spanish Code of Good Governance (CUBG, 2006) recommended that boards should have not less than five members and not more than fifteen. However, Burke et al. (2001) and Al-Mudhaki and Joshi (2004) argue that boards should have between three and six members, and Merino et al. (2009) found evidence to support a size of between three and twenty-two directors. Some studies (e.g. Eisenberg et al., 1998) have shown that the number of board members can affect supervisory and control functions, and the presence of too many directors may therefore hinder coordination and decision making. However, other authors (e.g. Sánchez et al., 2008) have claimed that a larger number of directors may permit more efficient control of the board's functions. Sánchez et al. (2008) also showed that the size of the board was positively related with executive pay, while Guest (2010) found a positive association between board size and directors' pay in the United Kingdom. Board size is denoted by "BDSIZE." This variable 
is calculated as the total number of board members. It is expected to be positive, as a larger board is likely to have more male members and, therefore, women will be in a minority and will be less well able to ensure compensation equality between male and female directors.

\section{Firm Fixed Effect}

The firm fixed effect control variable, denoted by "FIRM," is intended to capture unobservable and fixed characteristics of firms that may potentially be correlated with the dependent variable. Specifically, we include year indicator variables to control for yearly differences.

\subsection{Sample}

The initial sample comprised 1392 firms/year listed on the Madrid Stock Exchange between 2004 and 2011, inclusive. The information was obtained from the public registries kept by the Spanish National Securities Market Commission (CNMV), from the SABI data base and from corporate Web sites. Table 4 contains a description of the sample.

As may be observed in Table 4, the initial sample of 1392 firms/year did not include financial institutions because they are under special scrutiny by financial authorities that constrain the role of their board of directors and because of their special accounting practices. A further 749 industrial firms were excluded because not all the data necessary to test the model could be obtained, and the final sample thus comprised 515 observations. Most of the industrial firms were discarded because their Corporate Governance or Annual Reports did not contain details of directors' pay.

\section{Analysis of results}

\subsection{Descriptive statistics}

Table 5 shows the descriptive statistics for the dichotomous and continuous variables.

Panel A of Table 5 shows that $11 \%$, on average, of the Nomination and Compensation Committees have a female presence. In terms of educational level, an average $86 \%$ of female independent directors did not disclose their qualifications in the Corporate Governance Report, $8 \%$ were graduates and 6\% held doctoral degrees. Meanwhile, $10 \%$ of the firms in the sample belonged to FSEC (1) (Oil and energy), 30\% each to FSEC (2) (Commodities, industry, and construction) and FSEC (3) (Consumer goods), 9\% to FSEC (4) (Consumer services), 16\% to FSEC (5) (Financial and property services), and 5\% to FSEC (6) (Technology and telecommunications). Fifty-two percent of the firms are located in the Madrid region (GREG (3)), 17\% in the East of Spain (GREG (5)), 16\% in the Northeast (GREG 
Table 4 Sample description

\begin{tabular}{lrrrrrrrrr}
\hline & 2004 & 2005 & 2006 & 2007 & 2008 & 2009 & 2010 & 2011 & Total \\
\hline Initial sample of companies & 174 & 174 & 174 & 174 & 174 & 174 & 174 & 174 & 1392 \\
Companies excluded & $(109)$ & $(106)$ & $(115)$ & $(105)$ & $(104)$ & $(111)$ & $(110)$ & $(117)$ & $(877)$ \\
$\quad$ Industrial companies & 93 & 90 & 99 & 89 & 88 & 95 & 94 & 101 & 749 \\
$\quad$ Financial companies & 16 & 16 & 16 & 16 & 16 & 16 & 16 & 16 & 128 \\
Final sample of companies & 65 & 68 & 59 & 69 & 70 & 63 & 64 & 57 & 515 \\
& & & & & & & & & \\
\hline
\end{tabular}

(2)), $8 \%$ in the South and Canary Islands (GREG (6)), 5\% in the Northwest (GREG (1)), and 3\% in the Center (GREG (4)).

Ten percent of female directors had 1 year of seniority, 17\% had between 2 and 4 years and 7\% between 5 and 8 years of seniority, while $66 \%$ had no previous experience as a board member.

As may be observed in Panel B of Table 5, the mean logarithm of compensation differences between male and female directors is 6.914, which is to say that the pay received by men is on average 6.914 times higher than the women's pay. Also, the average percentage of women by board is $3 \%$, and the average company size is 13,130 (Natural logarithm of total assets), the productivity per employee is 5730, the return on assets is $6 \%$ and boards have 10.38 members on average.

\subsection{Univariate analysis}

Table 6 shows the mean values of the independent and control variables for the firms in the sample, as well as the results of the parametric $t$ test for the continuous variables, and Pearson's Chi-squared for the dichotomous variables to test for the presence of differences in means. The median (7.01) of the difference in the logarithm of male and female directors' pay was used to create the two groups.

As shown in Table 6, the difference in the means of the variable denoting the percentage of women on the board is positive, but not statistically significant, and the first hypothesis tested cannot therefore be accepted, as the gender pay gap between male and female directors is not affected by the percentage of women on the board. Thus, we cannot conclude that a greater percentage of female directors on the board will be more likely to result in a smaller gender pay gap among directors. Along the same lines, the variable denoting the presence of women on the Nomination and Compensation Committee reflects a positive difference in the means as predicted. However, this difference is not statistically significant, and the second hypothesis therefore cannot be accepted. The two variables ELIWBD (1) and ELIWBD (2), representing the educational level gained by female independent directors, displays 
Table 5 Descriptive statistics

\begin{tabular}{|c|c|c|c|c|c|}
\hline Variable & Mean & Standard deviation & Percentile 25 & Percentile 50 & Percentile 75 \\
\hline
\end{tabular}

Panel A: Dummy variables

\begin{tabular}{lll}
\hline PWNCC & 0.107 & 0.309 \\
ELIWBD (0) & 0.860 & 0.307 \\
ELIWBD (1) & 0.082 & 0.274 \\
ELIWBD (2) & 0.058 & 0.234 \\
FSEC (1) & 0.097 & 0.296 \\
FSEC (2) & 0.301 & 0.459 \\
FSEC (3) & 0.295 & 0.457 \\
FSEC (4) & 0.091 & 0.288 \\
FSEC (5) & 0.155 & 0.363 \\
FSEC (6) & 0.060 & 0.238 \\
GREG (1) & 0.047 & 0.211 \\
GREG (2) & 0.157 & 0.364 \\
GREG (3) & 0.520 & 0.500 \\
GREG (4) & 0.025 & 0.157 \\
GREG (5) & 0.175 & 0.380 \\
GREG (6) & 0.076 & 0.265 \\
SEN (0) & 0.660 & 0.448 \\
SEN (1) & 0.097 & 0.296 \\
SEN (2) & 0.169 & 0.375 \\
SEN (3) & 0.074 & 0.262 \\
\hline
\end{tabular}

Panel B: Continuous variables

\begin{tabular}{lrrrrr}
\hline REMU & 6.914 & 1.281 & 6.270 & 7.009 & 7.723 \\
PERCWBD & 0.030 & 0.067 & 0.000 & 0.000 & 0.000 \\
FIRMSIZE & 13.132 & 1.851 & 11.718 & 12.851 & 14.416 \\
PROD & 5.727 & 1.690 & 4.951 & 5.672 & 6.714 \\
ROA & 0.060 & 0.448 & -0.006 & 0.021 & 0.071 \\
BDSIZE & 10.383 & 3.506 & 8.000 & 10.000 & 12.000 \\
\hline
\end{tabular}

PWNCC: variable presence of women on the Nomination and Compensation Committee, which is calculated as a dummy variable that takes the value 1 if there is presence of women on the Nomination and Compensation Committee and 0, otherwise; ELIWBD (0): variable educational level of independent women on the board of directors, which is calculated as a dummy variable that takes the value 1 if independent female directors do not provide information about their educational level in the Corporate Governance Report and 0, otherwise; ELIWBD (1): variable educational level of independent women on the board of directors, which is calculated as a dummy variable that takes the value 1 if independent female directors 
have a degree and 0, otherwise; ELIWBD (2): variable educational level of independent women on the board of directors, which is calculated as a dummy variable that takes the value 1 if independent female directors have a doctorate and 0, otherwise; FSEC(1): variable firm sector, which is a dummy variable that takes the value 1 if the company operates in the oil and energy sector and 0 , otherwise; $\operatorname{FSEC}(2)$ : variable firm sector, which is a dummy variable that takes the value 1 if the company operates in the basic materials, industry and construction sector and 0 , otherwise; $\operatorname{FSEC}(3)$ : variable firm sector, which is a dummy variable that takes the value 1 if the company operates in the consumer goods sector and 0, otherwise; FSEC(4): variable firm sector, which is a dummy variable that takes the value 1 if the company operates in the consumer service sector and 0, otherwise; $\operatorname{FSEC(5):~variable~firm~sector,~which~is~a~dummy~}$ variable that takes the value 1 if the company operates in the finance and real estate sector and 0 , otherwise; $\operatorname{FSEC}(6)$ : variable firm sector, which is a dummy variable that takes the value 1 if the company operates in the technology and telecommunication sector and 0 , otherwise; GREG (1): variable geographical region, which is a dummy variable that takes the value 1 if the company is located in the North-Western region and 0, otherwise; GREG (2): variable geographical region, which is a dummy variable that takes the value 1 if the company is located in the North-Eastern region and 0, otherwise; GREG (3): variable geographical region, which is a dummy variable that takes the value 1 if the company is located in the Madrid region and 0 , otherwise; GREG (4): variable geographical region, which is a dummy variable that takes the value 1 if the company is located in the Center region and 0, otherwise; GREG (5): variable geographical region, which is a dummy variable that takes the value 1 if the company is located in the East region and 0, otherwise; GREG (6): variable geographical region, which is a dummy variable that takes the value 1 if the company is located in the South and the Canary Islands region and 0 , otherwise; SEN (0): variable seniority, which is a dummy variable that takes the value 1 if women directors on the board of directors do not have seniority and 0 , otherwise; SEN (1): variable seniority, which is a dummy variable that takes the value 1 if women directors on the board of directors have one year of seniority and 0, otherwise; SEN (2): variable seniority, which is a dummy variable that takes the value 1 if women directors on the board of directors have from 2 to 4 years of seniority and 0, otherwise; SEN (3): variable seniority, which is a dummy variable that takes the value 1 if women directors on the board of directors have from 5 to 8 years of seniority and 0, otherwise; REMU: variable gap in pay between male and female directors on the board of directors and is calculated as the log of the difference between male and female director's compensation in the board of directors; PERCWBD: variable percentage of women directors on the board of directors and is calculated as the ratio between the total number of female directors on the board of directors and the total number of directors on the board of directors; FIRMSIZE: variable firm size and is calculated as the log of total assets (in thousands of Euros); PROD: variable employee productivity and is calculated as the log of (turnover/number of employees); ROA: variable return on assets and is calculated as the ratio between ordinary result and average of total assets; BDSIZE: variable size of the board and it is calculated as the total number of directors on the board of directors. 
Table 6 Mean difference for independent and control variables

\begin{tabular}{|c|c|c|c|c|}
\hline Variable & $\begin{array}{l}\text { Median of the gender gap } \\
\text { in pay in the board of } \\
\text { directors } \geq 7.01 \\
(N=259)\end{array}$ & $\begin{array}{l}\text { Median of the gender } \\
\text { gap in pay in the } \\
\text { board of directors }<7.01 \\
(N=256)\end{array}$ & $\begin{array}{l}\text { Mean } \\
\text { difference }\end{array}$ & $\begin{array}{l}\text { Univariate } \\
\text { test (Sig.) }\end{array}$ \\
\hline PERCWBD & 0.032 & 0.028 & 0.004 & $0.819(0.413)$ \\
\hline PWNCC & 0.127 & 0.086 & 0.041 & $1.524(0.128)$ \\
\hline ELIWBD (1) & 0.093 & 0.070 & 0.023 & $0.926(0.355)$ \\
\hline ELIWBD (2) & 0.097 & 0.020 & 0.077 & $3.774^{* * *}(0.000)$ \\
\hline FSEC (1) & 0.178 & 0.016 & 0.162 & $6.441 * * *(0.000)$ \\
\hline FSEC (2) & 0.301 & 0.301 & 0.000 & $0.009(0.993)$ \\
\hline FSEC (3) & 0.208 & 0.383 & -0.175 & $-4.409^{* * *}(0.000)$ \\
\hline FSEC (4) & 0.120 & 0.063 & 0.057 & $2.260 * *(0.024)$ \\
\hline FSEC (5) & 0.127 & 0.184 & -0.057 & $-1.762 *(0.079)$ \\
\hline GREG (1) & 0.046 & 0.047 & -0.001 & $-0.029(0.977)$ \\
\hline GREG (2) & 0.127 & 0.188 & -0.061 & $-1.875 *(0.061)$ \\
\hline GREG (3) & 0.672 & 0.367 & 0.305 & $7.250^{* * *}(0.000)$ \\
\hline GREG (4) & 0.004 & 0.047 & -0.043 & $-3.135^{* * *}(0.002)$ \\
\hline GREG (5) & 0.116 & 0.234 & -0.118 & $-3.579 * * *(0.000)$ \\
\hline SEN (1) & 0.104 & 0.090 & 0.014 & $0.551(0.582)$ \\
\hline SEN (2) & 0.178 & 0.160 & 0.018 & $0.528(0.598)$ \\
\hline SEN (3) & 0.097 & 0.051 & 0.046 & $1.989 * *(0.047)$ \\
\hline FIRMSIZE & 14.131 & 12.122 & 2.009 & $14.661^{* * *}(0.000)$ \\
\hline PROD & 6.003 & 5.448 & 0.555 & $3.776^{* * *}(0.000)$ \\
\hline ROA & 0.100 & 0.021 & 0.079 & $2.015^{* *}(0.044)$ \\
\hline BDSIZE & 12.008 & 8.738 & 3.270 & $11.950 * * *(0.000)$ \\
\hline
\end{tabular}

PERCWBD: variable percentage of women directors on the board of directors and is calculated as the ratio between the total number of female directors on the board of directors and the total number of directors on the board of directors; PWNCC: variable presence of women on the Nomination and Compensation Committee, which is calculated as a dummy variable that takes the value 1 if there is presence of women on the Nomination and Compensation Committee and 0, otherwise; ELIWBD (1): variable educational level of independent women on the board of directors, which is calculated as a dummy variable that takes the value 1 if independent female directors have a degree and 0, otherwise; ELIWBD (2): variable educational level of independent women on the board of directors, which is calculated as a dummy variable that takes the value 1 if independent female directors have a doctorate and 0 , otherwise; FSEC(1): variable firm sector, which is a dummy variable that takes the value 1 if the company operates in the oil and energy sector and 0, otherwise; $\operatorname{FSEC}(2)$ : variable firm sector, which is a dummy variable that takes the value 1 if the company operates in the basic materials, industry, and construction sector and 0, otherwise; FSEC(3): variable firm sector, which is a dummy variable that takes the value 1 if the company operates in the consumer 
goods sector and 0, otherwise; FSEC(4): variable firm sector, which is a dummy variable that takes the value 1 if the company operates in the consumer service sector and 0 , otherwise; FSEC(5): variable firm sector, which is a dummy variable that takes the value 1 if the company operates in the finance and real estate sector and 0, otherwise; GREG (1): variable geographical region, which is a dummy variable that takes the value 1 if the company is located in the North-Western region and 0, otherwise; GREG (2): variable geographical region, which is a dummy variable that takes the value 1 if the company is located in the North-Eastern region and 0, otherwise; GREG (3): variable geographical region, which is a dummy variable that takes the value 1 if the company is located in the Madrid region and 0, otherwise; GREG (4): variable geographical region, which is a dummy variable that takes the value 1 if the company is located in the Center region and 0, otherwise; GREG (5): variable geographical region, which is a dummy variable that takes the value 1 if the company is located in the East region and 0, otherwise; SEN (1): variable seniority, which is a dummy variable that takes the value 1 if women directors on the board of directors have 1 year of seniority and 0, otherwise; SEN (2): variable seniority, which is a dummy variable that takes the value 1 if women directors on the board of directors have from 2 to 4 years of seniority and 0, otherwise; SEN (3): variable seniority, which is a dummy variable that takes the value 1 if women directors on the board of directors have from 5 to 8 years of seniority and 0, otherwise; FIRMSIZE: variable firm size and is calculated as the log of total assets (in thousands of Euros); PROD: variable employee productivity and is calculated as the log of (turnover/number of employees); ROA: variable return on assets and is calculated as the ratio between ordinary result and average of total assets; BDSIZE: variable size of the board and it is calculated as the total number of directors on the board of directors.

a positive difference in the means, although this is only statistically significant at the $1 \%$ level in the case of ELIWBD (2). Consequently, it is likely that at least one woman will hold a doctoral degree in those firms where the gender pay gap between male and female directors is widest. This finding is in line with the evidence reported by Palacio and Simón (2002) and Simón (2006). Meanwhile, it may be observed that the sector variables FSEC (1), FSEC (2), and FSEC (4) display a positive difference in the mean, although it is only statistically significant at the level of $1 \%$ in the case of FSEC (1) and 5\% in FSEC (4). Thus, the male-female compensation difference between directors is greater on the boards of firms belonging to the oil and energy sector and the consumer services sector. The difference in means is negative in FSEC (3) and FSEC (5) and is statistically significant at the level of $1 \%$ and $10 \%$, respectively. Therefore, we may conclude that the gender pay gap is smaller in the consumer goods sector and in financial services and property. Finally, we may observe that the geographical region variable GREG (3) presents a positive and statistically significant difference at $1 \%$. Consequently, the gap between the pay of male and female directors is greater in firms located in Madrid. Meanwhile, GREG (1), GREG (2), GREG (4) and GREG (5) show negative differences, which are statistically significant at $1 \%$ and $10 \%$ in all cases, except GREG (1). Hence, the gender pay gap among directors is lowest in firms located in the North-East, Center, and East of Spain. 
We may also observe that the difference in means of all of the control variables is positive and statistically significant, except in the case of SEN (1) and SEN (2). We may therefore conclude that the compensation difference between male and female directors will be greater in those firms larger where the board has more members and includes women with between 5 and 8 years of seniority, and in firms displaying the highest return on assets and with the highest employee productivity.

\subsection{Multivariate analysis}

The multivariate analysis looks at the results of the linear regression and the multicollinearity test.

Table 7 presents the results of the linear regression for the model proposed and for the six variants, where the dependent variable represents the logarithm of the gender pay gap among $\mathrm{BD}$.

Model 1 includes all the independent variables included in the study, comprising the characteristics of the board (PERCWBD, PWNCC, ELIWBD (1) and ELIWBD (2)), the sector (FSEC (i)) and the region (GREG (i)), while Models 2, 3, and 4 examine the impact of each of the independent variables in isolation. Specifically, Model 2 analyses board characteristics, Model 3 the sector and Model 4 the geographical region. Model 5 includes both the sector and the geographical region where the firm is located, excluding the variables referring to the characteristics of the board. Meanwhile, Model 6 analyses the variables referring to the board's characteristics and the sector, excluding the geographical region, and Model 7 includes the board's characteristics and the geographical region, excluding the sector variable.

The results for Model 1 show goodness of fit of $50-70 \%$, and the model is statistically significant at the $1 \%$ level. The variable denoting the percentage of female board members (PERCWBD) is negative, contrary to our expectations, but it is not statistically significant, and the hypothesis tested therefore cannot be accepted. Consequently, an increase in the percentage of women on the board has no effect on the gender pay gap between directors. According to this result, it cannot be confirmed that a higher percentage of women directors on the board will be more likely to result in a smaller gender wage gap among directors. Meanwhile, the variable denoting the presence of women on the Nomination and Compensation Committee (PWNCC) displays the expected sign and is statistically significant at the $5 \%$ level of significance. Hence, we can accept the second hypothesis proposed, concluding that the presence of women on the Nomination and Compensation Committee will increase the gender pay gap among board members. According to this result, we can confirm that the presence of female directors in the Nomination and Compensation Committee influences the gender wage gap, widening it. Both of the qualifications variables are negative, as expected, but only ELIWBD (1) is statistically significant at the $1 \%$ level. Thus, the third hypothesis can be accepted and we can conclude that the presence of well-qualified female independent directors on company boards will 


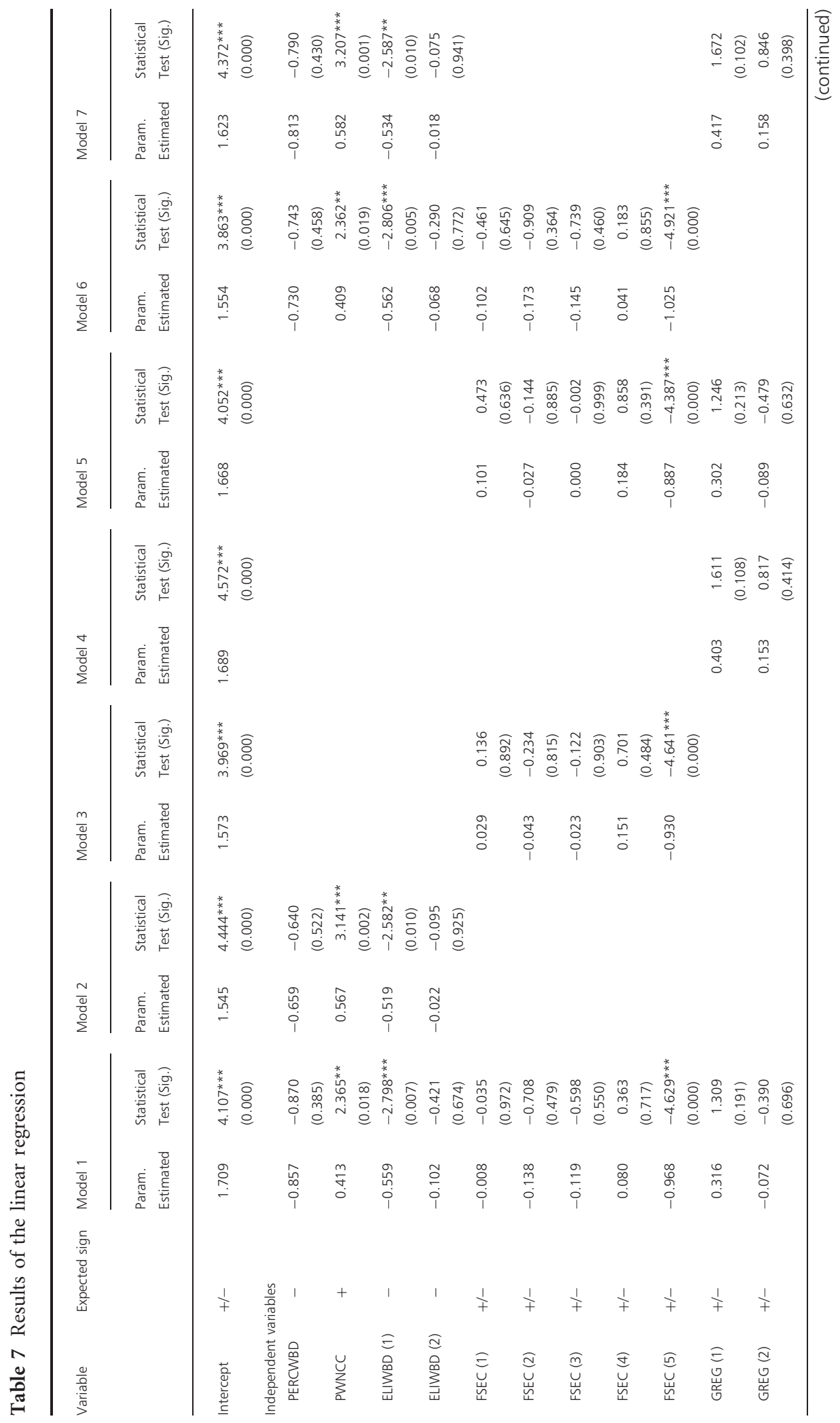




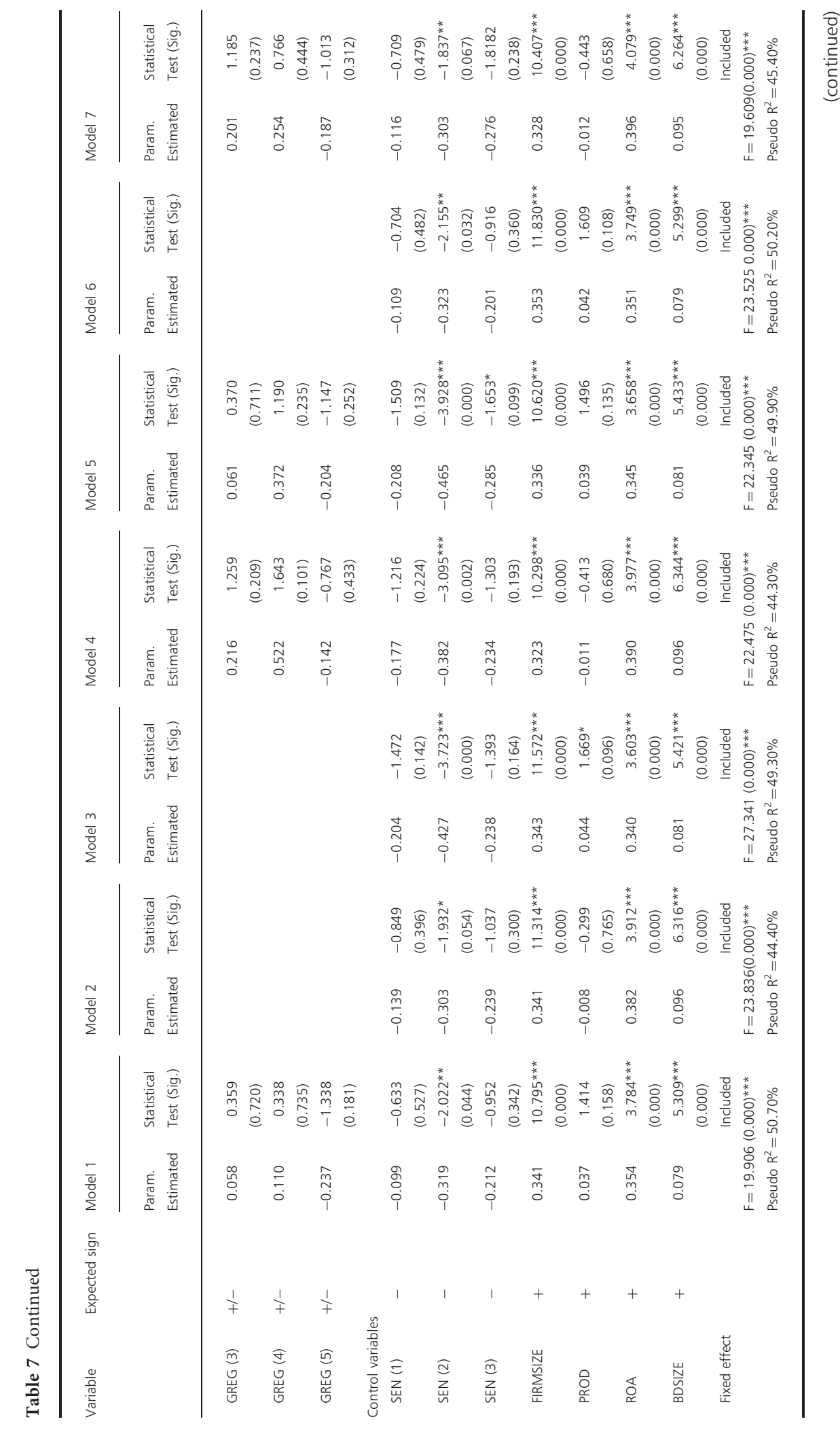




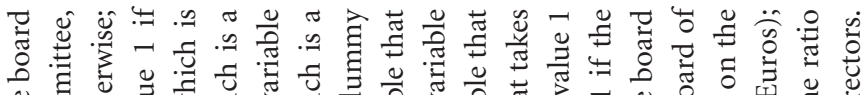

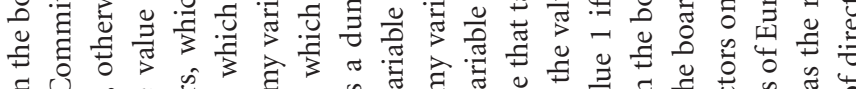

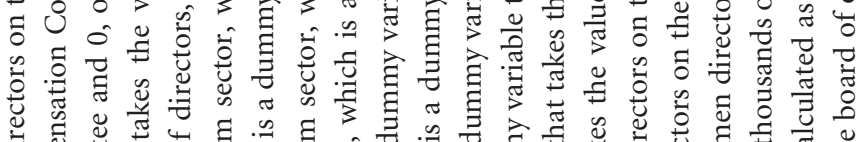

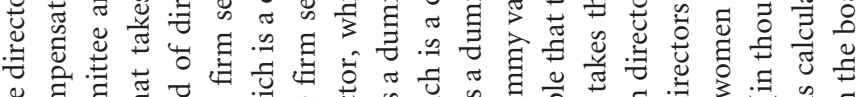

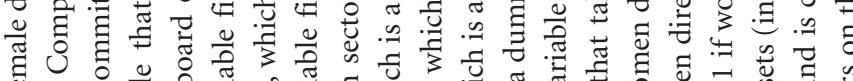

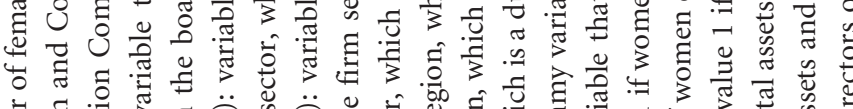

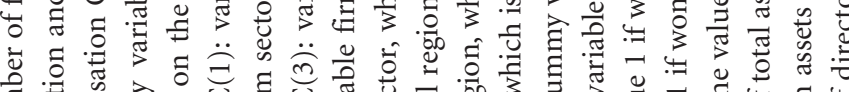

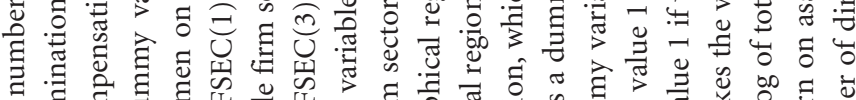

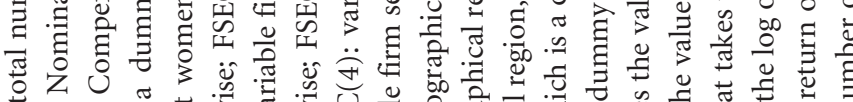

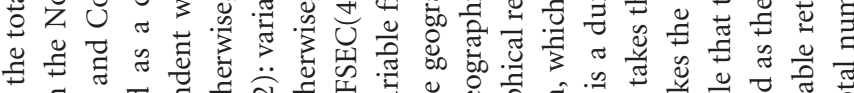

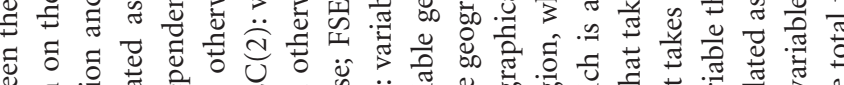

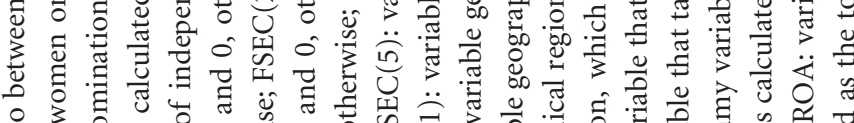

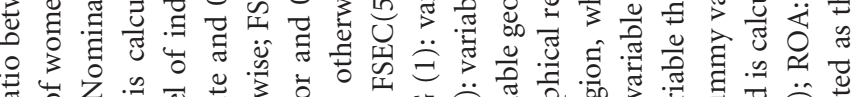

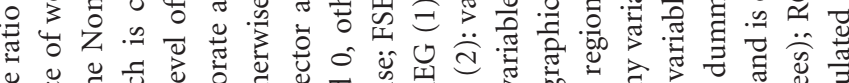

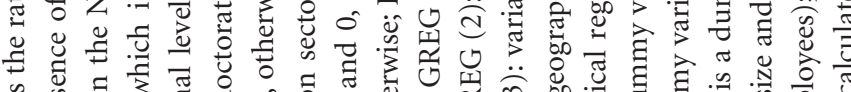

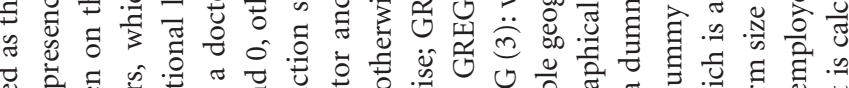

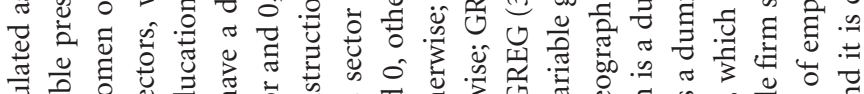

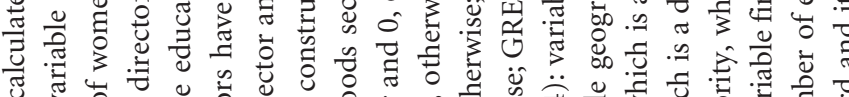
चु

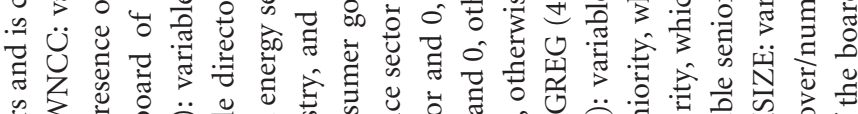

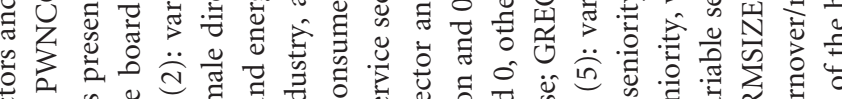

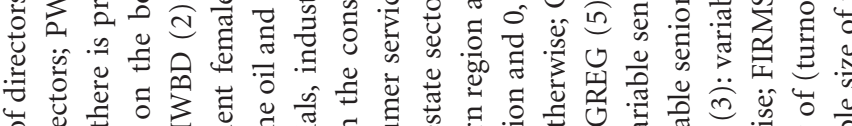

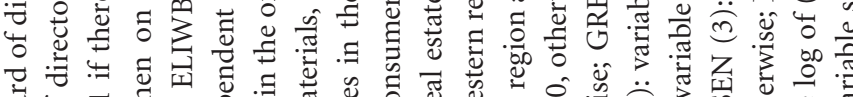

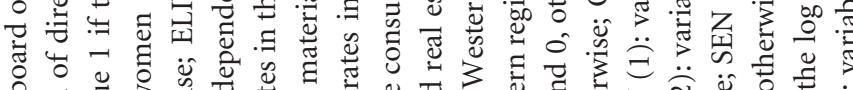

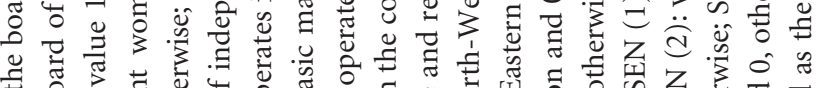

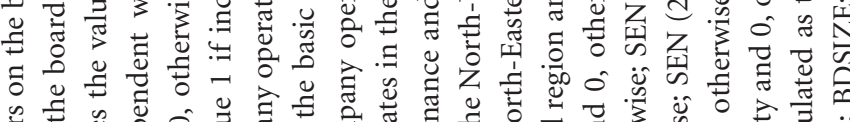

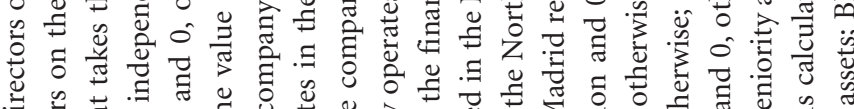

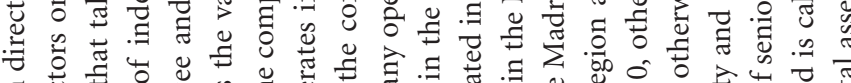

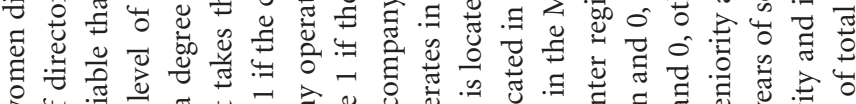

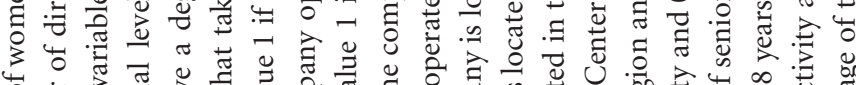

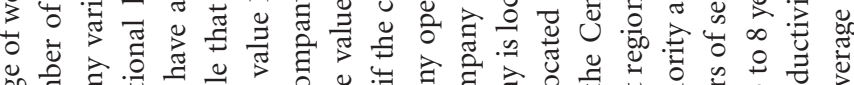

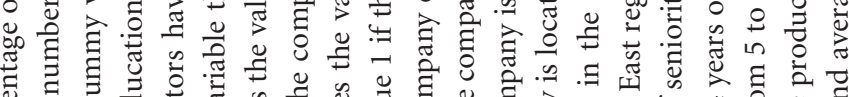

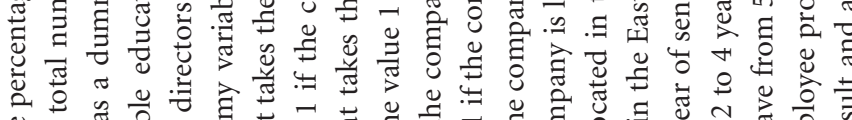

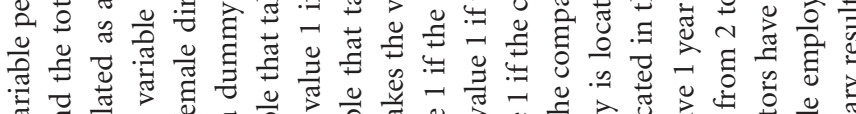

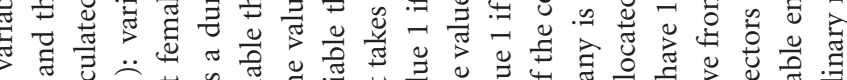

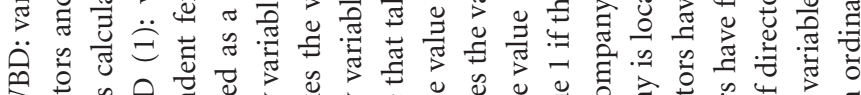

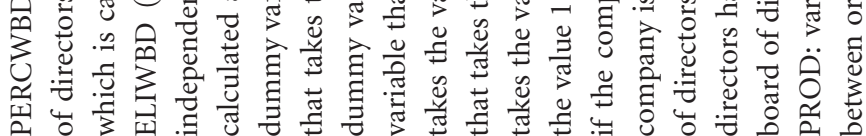


reduce the gender gap in pay among directors. In this light, we concur with Gardín and del Río (2009) and with Mukhopadhayay (2001) in confirming that the presence of female independent directors holding degree level qualifications reduces the gender pay gap between the men and women serving on a firm's board.

The sector variable is negative for all sectors, except consumer services SEC (4), which is positive. However, only financial services and property (FSEC 5) is statistically significant at $1 \%$. Hence, the fourth hypothesis is partially accepted, as only one of the five sectors analyzed has an effect on gender wage pay, reducing it, and therefore, we may conclude that in financial services and the property sector the gender gap is lower than in the others. None of the variables denoting geographical region is statistically significant, and the fifth hypothesis therefore cannot be accepted. Thus, it cannot be confirmed that geographical region affects the gender gap in pay, as none of the regions studied increased or narrowed the gender wage gap.

All the control variables offer the expected signs, but only the variables denoting the presence of female directors with between 2 and 4 years of seniority (SEN(2)), company size (FIRMSIZE), return on assets (ROA) and board size (BDSIZE) are statistically significant. We therefore concur with Aláez and Ullibarri (1999) and Lago (2002) that the presence of more experienced women (in terms of years of seniority) on company boards reduces male-female compensation difference between directors, and that the gender pay gap widens with company size, return on assets, and board size.

The results for Models 2, 3, and 4 are statistically significant at the $1 \%$ level and present goodness of fit of 44.50\%, 49.30\%, and 44.30\%, respectively. Model 2 analyses the individual influence of board characteristics (proportion of female board members, qualifications of independent female directors, and the presence of women on the Nomination and Compensation Committee) on the gender pay gap between directors. Model 2 confirms the results obtained from the analysis of all of the independent variables together, allowing the conclusion that the presence of women on the Nomination and Compensation Committee increases the gender pay gap between directors, while the presence of women graduates on company boards reduces male-female compensation differences. The control variables for Model 2 take the same signs at the same significance levels as in Model 1, except for the productivity variable, which is negative in this model, but it is once again not statistically significant, and SEN (3), which was not statistically significant in Model 1 but is so at the $10 \%$ level in Model 2.

The results obtained from Models 3 and 4, which respectively analyze the influence of the sector and geographical region of the firm, are very similar to those of Model 1. Specifically, the only independent sector variable to change in Model 3 is FSEC (1), which is positive where it was negative in Model 1. Once again, only FSEC (5) is statistically significant. The results for the control variables are also the same, except for employee productivity, which is statistically significant at the $10 \%$ level in Model 3, although it was not so in Model 1. Thus, an increase in employee 
productivity entails a widening of the gender pay gap between directors. In this light, we may again conclude that compensation differences between male and female directors are reduced only in the financial services and property sector. The results of Model 4 are the same as in Model 1, except in the case of employee productivity, which was positive in the latter, but is negative in Model 4 . However, this variable is not statistically significant in either model. In light of the results obtained in Model 4, we may conclude that the region where a firm is located has no effect on the gender pay gap between board directors.

Model 5 analyses the independent variables denoting the sector and geographical region together, while excluding board characteristics. The results obtained are the same as for Model 1. Only FSEC (5) is negative, and it is statistically significant at the $1 \%$ level. Hence, the gender pay gap between directors is smallest in the financial services and property sector. As in Model 1, the geographical region is not statistically significant. Meanwhile, there is practically no change in the control variables with the exception of SEN (3), which is statistically significant at the level of 10\% in Model 5.

Model 6 presents a goodness of fit of $50.20 \%$ and is statistically significant at the level of $1 \%$. The independent variables included in this model are the board characteristics (PERCWBD PWNCC, ELIWBD (1) and ELIWBD (2)) and the sector to which the firm belongs. As shown in Table 7, the results obtained from the independent and control variables included in Model 6 are the same as in Model 1, when all of the independent variables are examined together.

Finally, Model 7 analyses the independent variables consisting of board characteristics and the geographical region. It confirms the results revealed by Model 1, both for the independent and for the control variables. The only exception is the sign of GREG (2) and employee productivity, as the first of these variables is positive and the second is negative, contrary to the results found in Model 1. Neither is statistically significant, however. In Model 7 the control variable SEN (3) is also statistically significant.

To test for multicollinearity, we calculated the Spearman correlation coefficients for all of the variables included in the model. Table 8 shows the correlation matrix. Analysis of this table reports that the correlation between certain pairs of variables is statistically significant at the level of $5 \%$ or $10 \%$. These results are consistent with earlier studies of gender gap in pay (Gardín and Del Río, 2009; Ortega 2007). However, none of the correlation coefficients is sufficiently high $(>.80)$ to cause any major multicollinearity problems (see Archambeault and De Zoort, 2001). We have also calculated the vector inflation factor (VIF) to corroborate that our results are not biased because of the multicollinearity.

\section{Conclusions}

Cultural, political, and social changes in recent decades have seen women enter many jobs that were once reserved for men. However, the limited participation of women 


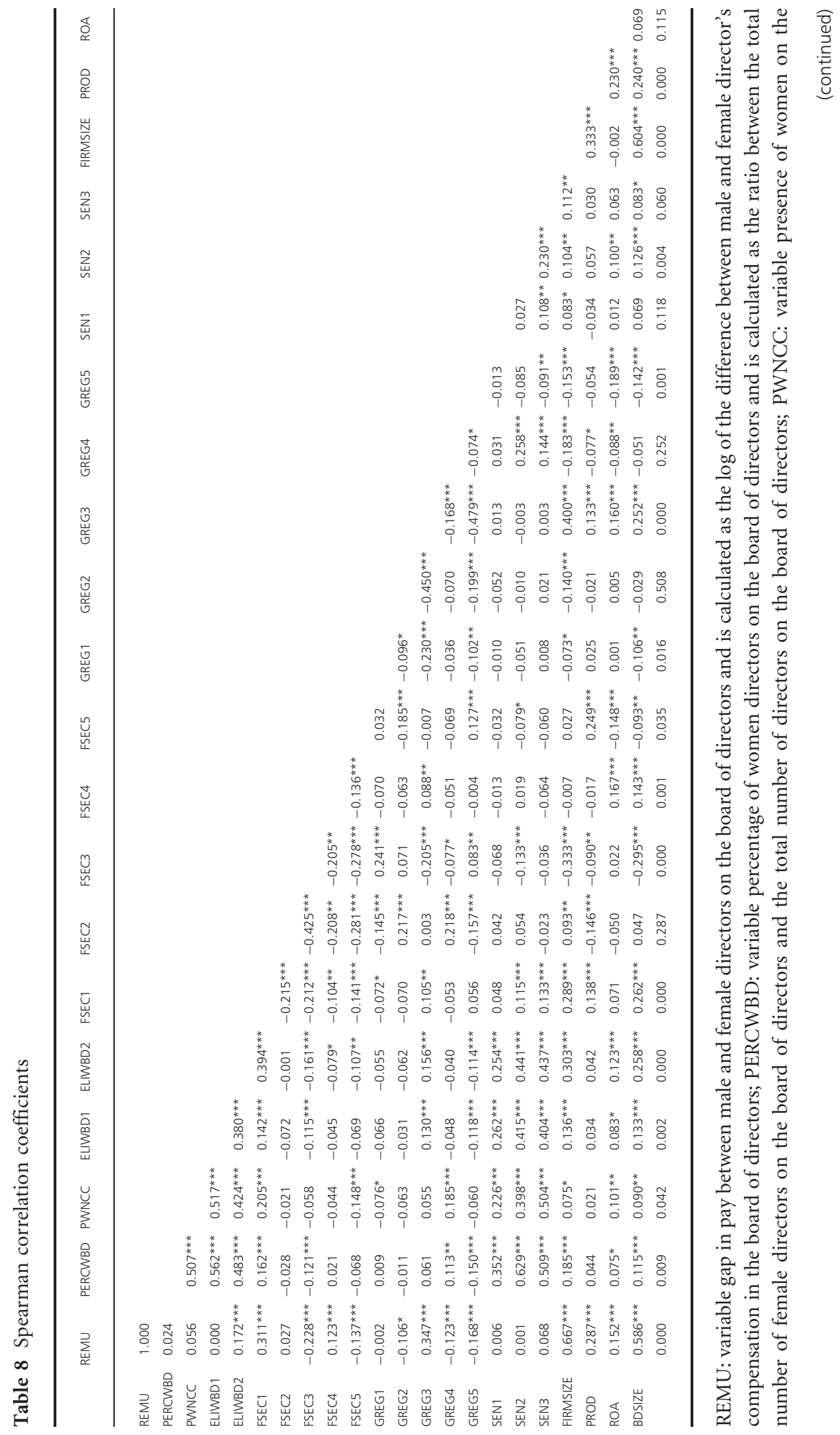




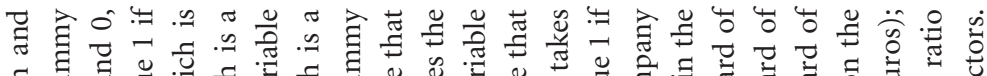

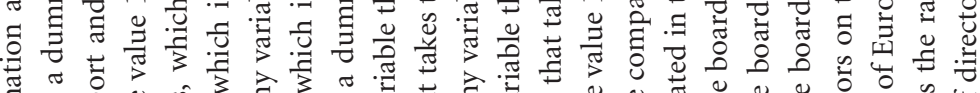

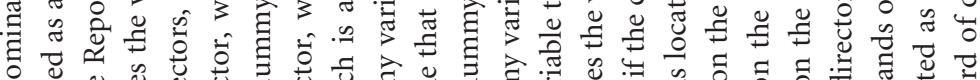

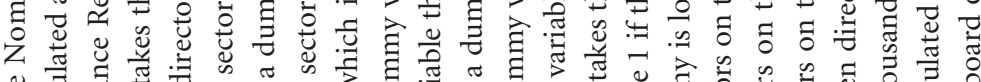

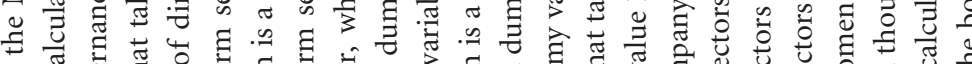

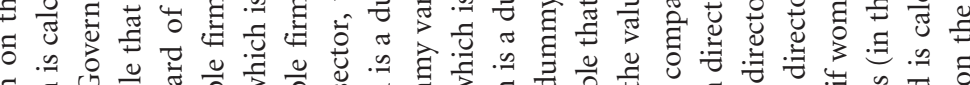

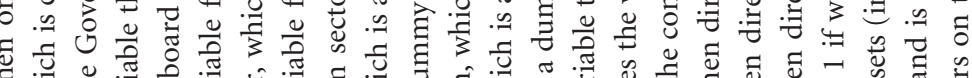

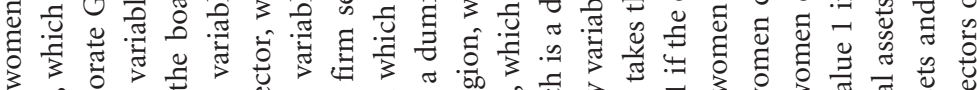

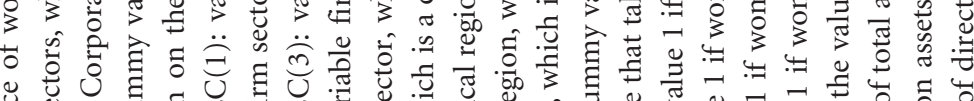

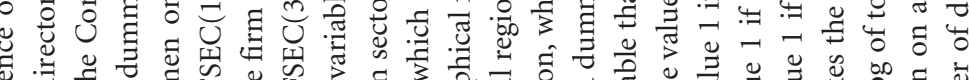

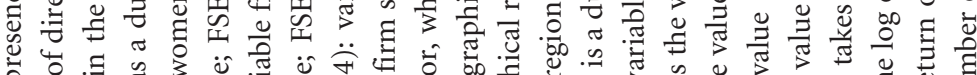

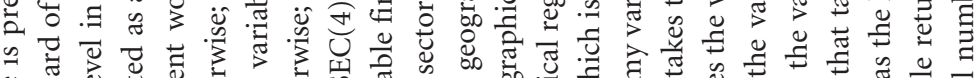

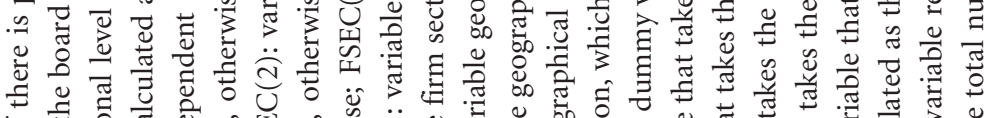

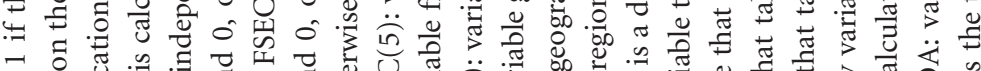

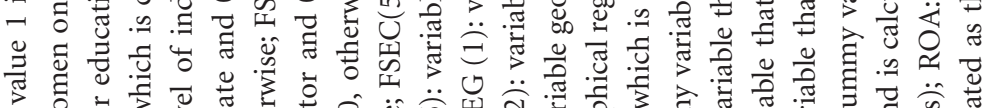

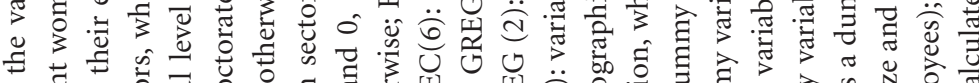

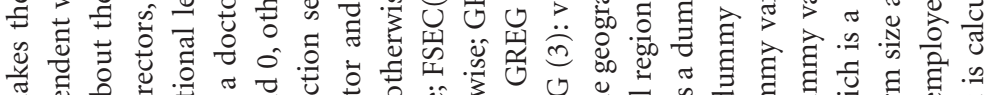

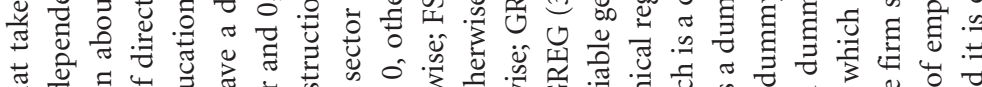

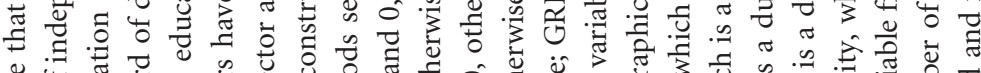

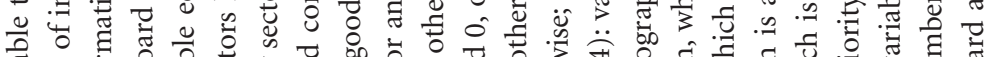

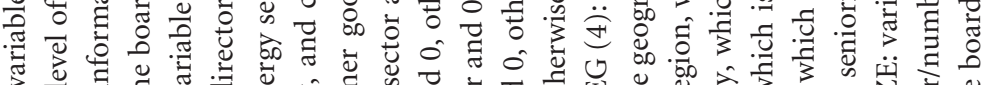

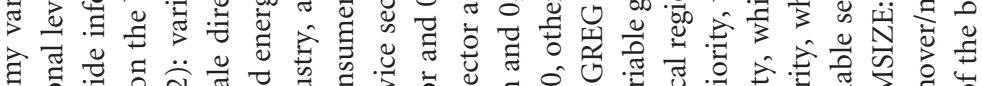

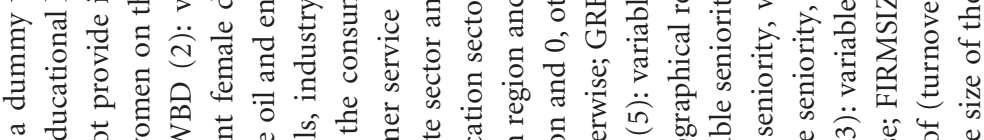

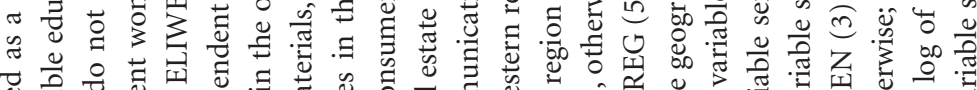

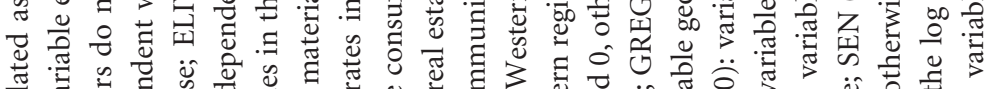

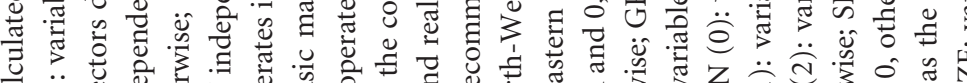

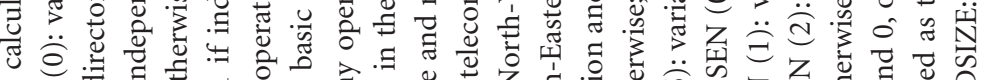

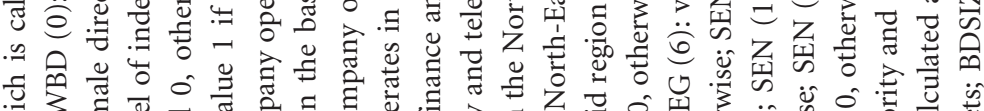

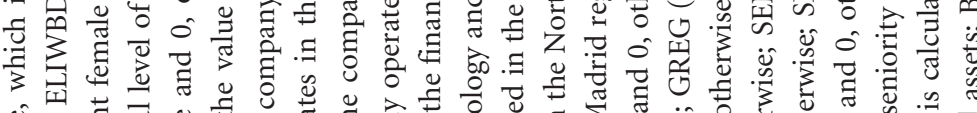
ง

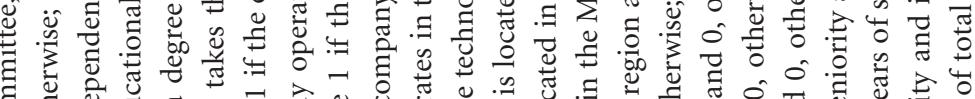

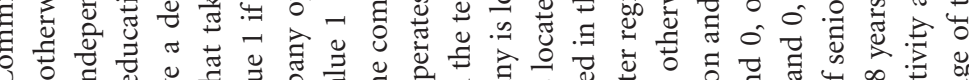

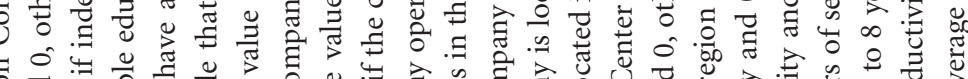

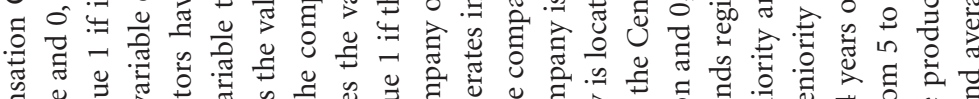

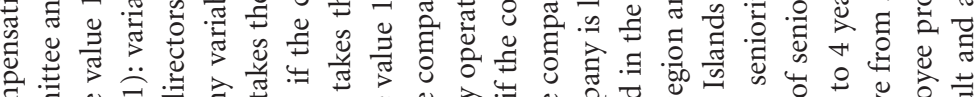

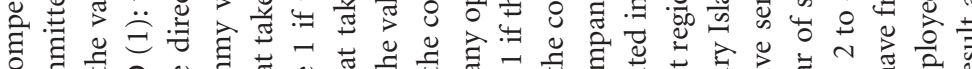
○

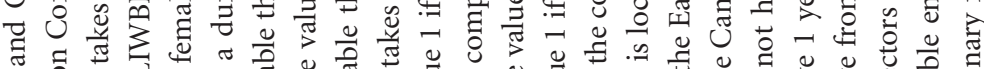

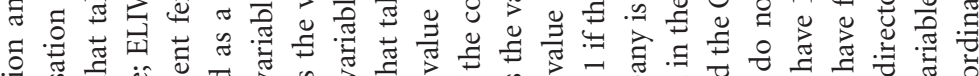

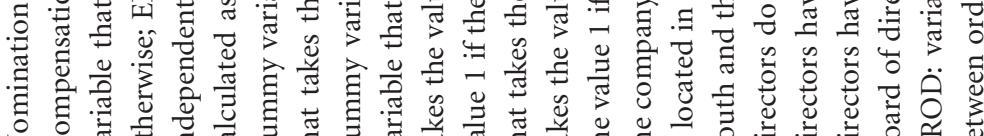

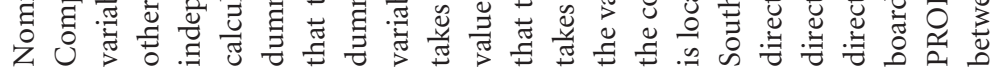


in the labor market has resulted in a gender pay gap. Numerous studies in Spain and internationally have investigated why such male-female compensation differences should exist (Campos et al., 2010; Mateos et al. 2010; Simón, 2009). To solve this problem, numerous regulations have been enacted to ensure that women are employed under equal conditions to men and to prevent male-female compensation discrimination.

The aim of this study was to determine whether there is a gender gap in pay among board directors of firms listed on the Madrid Stock Exchange, in the period 2004-2011, inclusive, and to throw light on the reason for any gender pay gap found.

To achieve this aim, we examined the effect of the percentage of female directors on the board, the presence of women on the Nomination and Compensation Committee, the educational level of female independent directors, the sector in which the firm operates and its geographical region, on the gender wage gap. The results obtained show that the percentage of female board members does not influence the gender pay gap among directors, while the presence of women on the Nomination and Compensation Committee actually widens the gap, as we predicted. The explanation for this may be that the opinion of women members on both the board and the Nomination and Compensation Committee is mitigated by their male colleagues. In particular, the few female members on Nomination and Compensation Committees are likely to come under considerable pressure in this regard, as these committees are small and are clearly dominated by men. Our results also report that the qualifications held by female independent directors influence board members' pay, as the presence of women graduates narrows the gender pay gap, but not for women who hold a $\mathrm{PhD}$. It may be that better corporate governance implies full disclosure of the director's background and reduced gender gap, rather than a relationship between the latter and the educational level. The results also suggest that the male-female compensation difference between directors is smaller in the boards of financial services and property sector firms (FSEC (5)). The geographical region in which the firm is located is not a relevant factor, as it does not affect the gender pay gap among board members. We believe that the explanation for these findings may be that the organizational culture of the firms listed on the Madrid Stock Exchange is influenced by the values of their directors rather than by the culture of a specific geographical region. This result may also be explained by the fact that the cost of living is similar in all the regions considered. With regard to the control variables used, we find that the presence of women with between 2 and 4 years of seniority on company boards reduces the gender pay gap between directors, but the gap increases in very large firms, where the return on assets is higher and where the board is larger. We have constructed different variations to validate and confirm the model originally proposed. The results obtained from these models basically confirm the findings from the original model, with some exceptions regarding the control variables.

The findings from this study reveal the existence of a gender gap in pay in the boards of firms listed on the Madrid Stock Exchange. Specifically, the study shows 
that female directors suffer pay discrimination when the Nomination and Compensation Committee has women members, in larger firms, in the most profitable firms (i.e. those with the highest return on assets), and in the firms with the largest boards. In contrast, the gender pay gap narrows when female independent directors are graduates, when the female board members have between 2 and 4 years of seniority and in firms operating in the financial services and property sector. Finally, we may observe that neither an increase in the proportion of female board members nor the geographical region of the firm have any particular influence on the gender pay gap. These findings, therefore, report that equality is still a long way off, and they should provide an incentive for regulators and politicians to press for changes to prevailing legislation to improve the situation and progress toward the elimination of male-female compensation discrimination at all levels. More effective laws are clearly needed to reduce the gender pay gap found and to oblige firms to comply on pain of sanctions.

The gender quota on boards, in our sample, rises from 1.04\% in 2004 to $6.62 \%$ in 2011. These data suggests that the Spanish quota is growing but not as much as is expected, considering that in 2015 the quota in listed firms should legally be $40 \%$ (a more in-depth discussion about this issue can be found in Terjesen et al., 2014). Thus, even though the regulations have been introduced, the time permitted for reaching gender equality is long ( 8 years) and for this reason, it may be possible that companies are not in a hurry to reach the gender quota of $40 \%$. In any case, we agree with Grosvold et al. (2007), who argue that a compulsory gender quota (affirmative action programs) may have the potential to generate growth in female representation in the boardroom and report that no negative effects of this initiative are likely to arise in the shape of the appointment of inexperienced female directors.

This study is subject to certain limitations. In the first place, the study was carried out in Spain for the period from 2004 to 2011, and the results obtained should therefore not be extrapolated to other countries or periods. Secondly, the literature refers to the analysis of individual attributes (gender, educational level, seniority, and experience), job attributes (type of contract, working hours, and occupation) and attributes of the workplace (sector, collective bargaining agreements, region, firm size, and compensation). Not all of this data (e.g. job attributes) could be obtained in this study; however, the database used contains information drawn from Corporate Governance Reports and Annual Reports, and from corporate websites. Thirdly, in this study we show association, not causation, between the presence of women on the Nomination and Compensation Committee, the educational level of independent women in the Board and the sector of the firm, and the difference between the compensation of male and female directors. Finally, it is likely that gender quotas law for Spanish boards has little effect because sanctions are weak in comparison to case from Norway, where the sanction if the company does not comply with the gender quota is extremely serve: the dissolution of the company. The only gender 
quota law similar to the Norwegian one in terms of effectiveness is the Italian one, introduced only in 2011.

This study may give rise to future lines of research. In the first place, an analysis of directors' pay, distinguishing between fixed and variable compensation, would be valuable in throwing light on the potential of incentives to narrow the gender pay gap. Second, it would be interesting to establish whether male-female compensation differences exist at all levels of an organization or merely on the board, assessing the equality plans applied by firms in their recruitment and selection processes. Third, it would be relevant to examine employee pay taking into account the wages of immigrant workers to establish whether firms discriminate in this area. Finally, it would also be interesting to study the pay earned by both male and female directors in international firms and to establish whether any gender-based compensation differences that may come to light are due to political, cultural, or social factors.

\section{Acknowledgements}

This work was supported by the Research Agency of the Spanish Government [Project ECO2011-29144-C03-02].

\section{References}

Act 3/2007 of 22 March, for Effective equality between women and men (LOIMH), (BOE 23 March 2007).

Act 2/2011 of 4 March, Sustainable economy, (BOE 5 March 2011).

Adams, R. B. and D. Ferreira (2003), 'Diversity and incentives: evidence from corporate boards,' Working Paper, Stockholm School of Economics, Estocolmo, Suecia, http://www. sbe.org.br/dated/ebe24/052.pdf.

Adams, R. B. and D. Ferreira (2009), 'Women in the boardroom and their impact on governance and performance,' Journal of Financial Economics, 94, 291-309.

Adler, R. D. (2001), 'Women in the executive suite correlate to high profits,' Working Paper. Harvard Business Review Pepperdine University, pp. 1-8.

Aláez, R. and M. Ullibarri (1999), 'Discriminación salarial por sexo: un análisis del sector privado y sus diferencias salariales,' Información Comercial Española (ICE): Revista de economía, 789, 117-138.

Aláez, R. J. C., M. Longás and M Ullibarri (2011), 'Visualising gender wage differences in the European Union,' Gender, Work and Organization, 18, 49-87.

Aldama Report (2003), Informe de la Comisión Especial para el fomento de la transparencia y la Seguridad en los mercados financieros y en las sociedades cotizadas. Ministerio de Economía y Hacienda: Madrid. 
Al-Mudhaki, J. and P. L. Joshi (2004), 'The role and functions of Audit Committees in the Indian Corporate Governance: empirical findings,' International Journal of Auditing, 8, 33-47.

Amarante, V. and A. Espino (2001), 'La evolución de la segregación laboral por sexo en Uruguay. 1986-1999,' Documento de Trabajo 3/01, Instituto de Economía, Facultad de Ciencias Económicas y de Administración, Universidad de la República de Uruguay.

Amarante, V. and A. Espino (2002), 'La segregación ocupacional de género y las diferencias en las remuneraciones de los asalariados privados (1990-2000),' Serie Avances de Investigación, DT 05/02, Instituto de Economía, Facultad de Ciencias Económicas y de Administración, UDELAR.

Archambeault, D. and F. T. DeZoort (2001), 'Auditor opinion shopping and the Audit Committee: an analysis of suspicious auditor switches,' International Journal of Auditing, $5,33-52$.

Arrazola, M. and J. Hevia (2009), 'Discriminación salarial, oferta salarial y salarios de reserva en España,' http://hdl.handle.net/10115/2785.

Arrondo, R., C. Fernández and E. Fernández (2008), 'Influencia de la estructura de gobierno corporativo sobre la remuneración de los consejeros en el mercado Español,' Tribuna de Economía, 844, 187-203.

Arulampalam, W., A. Booth and M. Bryan (2007), 'Is there a glass ceiling over Europe? Exploring the gender pay gap across the wages distribution,' Industrial and Labor Relation Review, 60(2), 163-186.

Barceinas, F., J. Oliver, J. L. Raymond and J. L. Roig (2000), 'Los rendimientos de la educación en España,' Papeles de Economía Española, 86, 128-148.

Bayard, K., J. Hellerstein, D. Neumark and K. Troske (1999), 'New evidence on sex segregation and sex differences in wages from matched employee-employer data,' Journal of Labor Economics, 21(4), 887-923.

Becker, G. S. (1964), Human Capital: A Theoretical and Empirical Analysis, with Special Reference to Education. the University of Chicago Press: London.

Bell, L. A. (2005), 'Women-led firms and the gender gap in top executive jobs,' Discussion Paper Series, 1689, 1-40. Institute for the Study of Labor, Bonn, Germany. Available at http://hdl.handle.net/10419/33391.

Bertrand, M. and K. Hallock (2001), 'The gender gap in top corporate jobs,' Industrial and Labor Relations Review, 55, 3-21.

Bilimoria, D. (2006), 'The relationship between women corporate directors and women corporate officers,' Journal of Managerial Issues, 18(1), 47-61.

Bird, B. M., J. Harrison and J. R. O’Malley (2007), 'Enterprise accountants, managerial status and gender salaries,' Journal of Diversity Management, 2(3), 23-36.

Blau, F. D. and L. M. Kahn (1992), 'The gender earnings gap: learning from international comparisons,' American Economic Review, 82, 533-538.

Blau, F. D. and L. M. Kahn (2001), 'Understanding international differences in the gender pay gap,' Working Paper No. 8.200, April, 2001, National Bureau of Economic Research. 
Blau, F. and L. M. Kahn (2007), 'The gender pay gap: have women gone as far as they can?' Academy of Management Perspectives, 1(1), 7-23.

Blomström, M. (1985), 'El comportamiento de las empresas nacionales y extranjeras en México,' Fondo de Cultura Económica, 175-194.

Böheim, R., H. Helmut and C. Zulehner (2007), 'Wage differences between Austrian men and women: semper idem?' Empirica, 34, 213-229.

Bowlin, W. and C. Renne (2008), 'Assessing gender and top-management-team pay in S\&P mid-cap and small-cap,' European Journal of Operational Research, 185(1), 430-437.

Burgess, Z. and P. Tharenou (2002), 'Women board directors: characteristics of the few,' Journal of Business Ethics, 37(1), 39-49.

Burke, R. (2000), 'Women on corporate boards of directors: Understanding the context,' in R. Burke and M. Mattis (eds), Women on Corporate Boards of Directors: International Challenges and Opportunities. Kluwer Academic Publishers: Doordrecht.

Burke, F., D. Guy and K. Tatum (2001), Audit Committees: A Guide for Directors, Management, and Consultants. Aspen Law \& Business: New York, NY.

Campbell, K. and A. Mínguez (2008), 'Gender diversity in the Boardroom and firm financial performance,' Journal of Business Ethics, 83, 435-451.

Campos, J. A., B. Ortega and M. A. Ropero (2010), 'Efectos de la segregación sobre las diferencias salariales de género en la hostelería andaluza: Una comparación entre distintas zonas turísticas,' Revista de Estudios Regionales, 89, 43-65.

Carli, L. J. (1990), 'Gender, language, and influence,' Journal of Personality and Social Psychology, 59(5), 941-952.

Carter, D., B. Simkins and W. Simpson (2003), 'Corporate governance, board diversity, and firm value,' The Financial Review, 38(1), 33-53.

Castaño, C., J. Martín, S. Vázquez and J. L. Martínez (2008), 'Más es menos: las directivas españolas ante los retos personales y profesionales,' Working Paper, disponible en, http:// www.asepuc.org/banco/castanomartinvazquezmartinez_carmoan2008.pdf (Consultado el día 31 de marzo de 2012).

Catalyst (1993), Women on Corporate Boards: The Challenge of Change. Catalyst: New York, NY.

Catalyst (2004), The Bottom Line: Connecting Corporate Performance and Gender Diversity. Catalyst: New York, NY.

Chevalier, A. (2007), 'Education, occupation and career expectations: determinants of the gender pay gap for UK graduates,' Oxford Bulletin of Economics and Statistics, 69(6), 819-842.

Cho, D. (2007), 'Why is the gender earnings gap greater in Korea than in the United States?' Journal of the Japanese International Economies, 21, 455-469.

Chu Ng, Y. (2004), 'Economic development, human capital, and gender earnings differentials in China,' Economics of Education Review, 23, 587-603.

Christie, P. and M. Shannon (2001), 'Educational attainment and the gender wage gap: evidence from the 1986 and 1991 Canadian censuses,' Economics of Education Review, 20, 165-180. 
Cohen, P. N. and M. L. Huffman (2007), 'Working for the woman? Female managers and the gender wage gap,' American Sociological Review, 72(5), 681-704.

Coelho Duarte, C. M., J. P. Esperança, J. D. Curto, M. C. Santos and M. Carapeto (2010), 'The determinants of gender pay gap in Portuguese private firms,' Gender in Management: An International Journal, 25(6), 438-461.

Consejo Económico y Social (2011), Tercer Informe sobre la situación de las mujeres en la realidad socio laboral española. Número 01/2011.

Conyon, M. J. (1997), 'Corporate Governance and executive compensation,' International Journal of Industrial Organization, 15, 493-509.

Crossley, T., S. Jones and P. Kuhn (1994), 'Gender differences in displacement cost,' Journal of 10 Human Resources, 29, 461-480.

De Anca, C. (2008), 'Women on corporate boards of directors in Spanish listed companies,' Women on Corporate Boards of Directors: International Research and Practice, 79-87.

De la Rica, S. (2003), 'Decomposing the gender wage gap: the effects of firm, occupation and job stratification,' Working Paper, 64, 1-8 Center for Labor Economics, University of California.

De la Rica, S. (2007), 'Segregación ocupacional y diferencias salariales por género en España: 1995-2002,' Documento de Trabajo 2007-38 serie 4, FEDEA.

De la Rica, S. and A. Ugidos (1995), ‘ ¿Son las diferencias de capital humano determinantes de las diferencias salariales observadas entre hombres y mujeres?' Investigaciones Económicas, 9(3), 395-414.

De Pablos, L. (2001), 'Desigualdad laboral y desde la perspectiva de género,' Documentos de trabajo de la Facultad de Ciencias Económicas y Empresariales, $N^{\circ}$ 5. Universidad Complutense de Madrid: Madrid, España.

Del Río, C., C. Gardín and O. Cantó (2011), 'The measurement of gender wage discrimination: the distributional approach revisited,' Journal of Economic Inequality, 9, 57-86.

Dolado, J., F. Felgueroso and J. F. Jimeno (2004), 'Where do women work? Analysis patterns of occupational segregation by gender,' Annales d'Economie et de Statistique, 71-72, 293-315.

Doménech, R. (2008), 'La evolución de la productividad en España y el capital Humano,' Fundación Alternativas, Documento de Trabajo no. 141/2008, Madrid.

Eisenberg, T., S. Sundgreen and M. T. Wells (1998), 'Larger board size and decreasing firm value in small firms,' Journal of Financial Economics, 48(1), 35-54.

EU Strategy Plan for gender equality from June 7 (2000).

Fan, C. S. and H. -L. Lui (2003), 'Structural change and the narrowing gender gap in wages: theory and evidence from Hong Kong,' Labour Economics, 10, 609-626.

Farrel, K. and P. Hersch (2005), 'Additions to corporate boards: the effect of gender,' Journal of Corporate Finance, 11(1), 85-106.

Fernández Méndez, C., R. Arrondo and E. Fernández (2011), 'Incidencia de las comisiones de nombramientos y retribuciones sobre las remuneraciones de los consejeros ejecutivos,' Cuadernos de Economía y Dirección de la Empresa, 15(1), 33-41. 
Fondas, N. and S. Sassalos (2000), 'A different voice in the boardroom: how the presence of women directors affects Board influence over management,' Global Focus, 12, 13-22.

García, J., P. J. Hernández and A. López-Nicolás (2001), 'How wide is the gap? An investigaion of gender wage differences using quantile regression,' Empirical Economics, 29, $149-168$.

Gardín, C. and C. Del Río (2009), 'Aspectos distributivos de las diferencias salariales por razón de género en España: Un análisis por subgrupos poblacionales,' Revista de Economía Pública, 189, 9-46.

Gartner, H. and G. Stephan (2004), 'How collective contracts and works councils reduce the gender wage gap,' Discussion paper, No. 2004, 7, http://hdl.handle.net/10419/31926.

Gomez-Mejia, L. R., H. Tosi and T. Hinkin (1987), 'Managerial control, performance and executive compensation,' Academy of Management Journal, 30(1), 51-70.

González Menéndez, M. and L. Martínez González (2012), 'Spain on the Norwegian pathway: towards a gender-balanced presence of women on corporate boards,' in C. Fagan, M. González Menéndez and S. Gómez Ansón (eds), Women on Corporate Boards and in Top Management: European Trends and Policy. Macmillan: Palgrave.

Gonzalo, M. T. and E. Pons (2001), 'Importancia de las expectativas laborales en el salario finalmente obtenido por las mujeres,' Documents de Treball del Departament d'Anàlisis Econòmica, $N^{\circ}$ 5. Universidad de Valencia: Valencia, España.

Gosling, A. and T. Lemieux (2001), 'Labour market reforms and changes in wage inequality in the United Kingdom and the United States,' in D. Card, R. Blundell and R. B. Freeman (eds), Seeking a Premier Economy: The Economic Effects of British Economic Reforms, 1980 2000. The University of Chicago Press: London. Available at: http://www.nber. org/chapters/c6750.

Groshen, E. (1991), 'The Structure of the female/male wage differential: is it who you are, what you do, or where you work?' The Journal of Human Resources, 26(3), 457-472.

Grosvold, J., S. Brammer and B. Rayton (2007), 'Board diversity in the United Kingdom and Norway: an exploratory analysis,' Business Ethics: A European Review, 16(4), 344-357.

Guest, P. M. (2010), 'Board structure and executive pay: evidence from the UK,' Cambridge Journal of Economics, 34, 1075-1096.

Guisán, M. C. and E. Aguayo (2008), 'Salario, empleo y productividad de la economía española en 1965-2008,' Estudios Económicos de Desarrollo Internacional, 8(1), 99-124.

Haltiwanger, J., J. Lane and J. Spletzer (2007), 'Wages, productivity and the dynamic interaction of businesses and workers,' Labour Economics, 14(3), 576-602.

Heilman, M. E. and M. C. Haynes (2005), 'No credit where credit is due: attributional rationalization of women's success in male-female teams,' Journal of Applied Psychology, 90(5), 905-916.

Heinze, A. and E. Wolf (2010), 'The intra-firm gender wage gap: a new view on wage differentials based on linked employer-employee data,' Journal of Popular Economic, 23, 851-879. 
Hernández, P. J. (1995), 'Análisis empírico de la discriminación salarial de la mujer en España,' Investigaciones Económicas, 19(2), 195-215.

Hillman, A. J., A. A. CannellaJr and I. C. Harris (2002), 'Women and racial minorities in the boardroom: how do directors differ?' Journal of Management, 28(6), 747-763.

Holst, E. (2006), Women in Managerial Positions in Europe: Focus on Germany (No. 557), DIWDiskussionspapiere, German Institute for Economic Research: Berlin, Germany.

Holst, E. and A. Busch (2009), Glass Ceiling Effect and Earnings: The Gender Pay Gap in Managerial Positions in Germany. German Institute for Economic Research: Berlin, Germany.

Huse, M. and A. G. Solberg (2006), 'Gender-related boardroom dynamics: how Scandinavian women make and can make contributions on corporate boards,' Women in Management Review, 21(2), 113-130.

Iranzo, S., F. Schivardi and E. Tosetti (2006), 'Skill dispersion and firm productivity: an analysis with employer-employee matched data,' Journal of Labor Economics, 26(2), 247-285.

Ittonen, K., J. Miettinen and S. Vähämaa (2010), 'Does female representation in audit committees affect audit fees?' Quarterly Journal of Finance and Accounting, 49(3-4), 113-139.

Izquierdo, M. and A. Lacuesta (2007), 'Wage inequality in Spain-recent developments,' Working Paper Series 781, European Central Bank: Frankfurt.

Jacobs, J. (1992), 'Women's entry into management: trends in earnings, authority and values among salaried managers,' Administrative Science Quarterly, 37(2), 282-301.

Johnson, G. and G. Solon (1986), 'Estimates of the direct effects of comparable worth policy,' American Economic Review, 76(5), 1117-1125.

Jolliffe, D. (2002), 'The gender wage gap in Bulgaria: a semiparametric estimation of discrimination,' Journal of Comparative Economics, 30, 276-295.

Jordan, Ch. E., S. J. Clark and M. A. Waldron (2007), 'Gender bias and compensation in the executive suite of the Fortune 100,' Journal of Organizational Culture, Communications and Conflict, 11(1), 19-29.

Jurajda, S. (2003), 'Gender wage gap and segregation in enterprises and the public sector in late transition countries,' Journal of Comparative Economics, 31, 199-222.

Jurajda, S. and H. Harmgart (2007), 'When do female occupations pay more?' Journal of Comparative Economics, 35, 170-187.

Klein, A. (1998), 'Firm performance and board committee structure,' Journal of Law and Economics, 41(1), 275-303.

Klein, A. (2003), 'Likely effects of stock exchange governance proposals and Sarbanes-Oxley on corporate boards and financial reporting,' Accounting Horizons, 17, 343-355.

Kose, J. and W. Lemma (1998), 'Corporate governance and Board effectiveness,' Journal of Banking and Finance, 22, 371-403.

Krishnan, H. and D. Park (2005), 'A few good women-on top management teams,' Journal of Business Research, 58(12), 1712-1720. 
Kulich, C., T. Grzegorz, K. R. S. Michelle, H. Alexander and D. R. R. Luc (2011), 'Who gets the carrot and who gets the stick? Evidence of gender disparities in executive remuneration,' Strategic Management Journal, 32(3), 301-321.

Kunze, A. (2005), 'The evolution of the gender wage gap,' Labour Economics, 12, 73-97.

Lago, I. (2002), 'La discriminación salarial por razón de género: Un análisis empírico del sector privado de España,' Revista Española de Investigaciones Sociológicas (REIS), 98, 171-196.

Lauer, C. (2000), Gender wage gap in West Germany: How Far Do Gender Differences in Human Capital Matter? Centre for European Economic Research (ZEW): Mannheim.

Lazear, E. and S. Rosen (1990), 'Male-female wage differentials in urban labor markets,' Journal of Labor Economics, 1, 106-123.

Law 44/2002, of 22 November, Law on Measures to Reform the Financial System (LMRFS).

Law 26/2003, Spanish Listed Companies Transparency Act.

Leaker, D. (2008), 'The gender pay gap in the UK,' Economic and Labour Market Review, 2(4), $19-31$.

Lips, H. M. (2003), 'The gender pay gap: concrete indicator of women's progress toward equality,' Analyses of Social Issues and Public Policy, 3(1), 87-109.

Lips, H. M. (2008), 'The gender wage gap: debunking the rationalizations WomensMedia.com,' http://www.womensmedia.com/new/Lips-Hilarygender-wage-gap. shtml (accessed 11 October 2010).

MacPherson, D. and H. Hirsch (1995), 'Wages and gender composition: why do women's jobs pay less?' Journal of Labor Economics, 13(3), 426-471.

Manzaque, M., E. Merino and R. Banegas (2008), 'Estructura de la propiedad y retribución de la dirección. Evidencia empírica para las empresas españolas cotizadas, Seminario Permanente de Ciencias sociales. Documento de Trabajo 2008/7.

Mateos, R., R. Gimeno and L. Escot (2010), 'Discriminación en Consejos de Administración: análisis e implicaciones económicas,' Revista de Economía Aplicada, 18(53), 131-162.

Mateos, R, J. Iturrioz and R. Gimeno (2007), 'Aplicación del análisis discriminante al papel de la mujer en los Consejos de Administración: el caso de las sociedades cooperativas,' Empresa global y mercados locales: XXI Congreso Anual AEDEM, Universidad Rey Juan Carlos, Madrid, 6,7 y 8 de junio de 2007.

Merino, E., M. Manzaque and R. Banegas (2009), 'Retribución y composición del Consejo de Administración. Evidencia empírica para las empresas cotizadas españolas,' Pecvnia, 8, 203-234.

Mincer, J. and S. Polachek (1974), 'Family investments in human capital: earnings of women,' Journal of Political Economy, 82, 76-108.

Mirta, A. (2003), 'Establishment size, employment, and the gender wage gap,' Journal of SocioEconomics, 32, 317-330. 
Miyoshi, K. (2008), 'Male-female wage differentials in Japan,' Japan and the World Economy, 20, 479-496.

Monk, E. and C. Turner (2004), 'The gender wage gap in South Korea: how much has changed in 10 years?' Journal of Asian Economics, 15, 415-424.

Mukhopadhaya, P. (2001), 'Changing labor-force gender composition and male-female income diversity in Singapore,' Journal of Asian Economics, 12(4), 547-568.

Newel, A. and B. Reilly (1996), 'The gender wage gap in Russia: some empirical evidence,' Labour Economics, 3, 337-356.

Nielsen, S. and M. Huse (2010), 'The contribution of women on Boards of Directors: going beyond the surface,' Corporate Governance: An International Review, 18(2), 136-148.

Olivence Report (1998), El buen Gobierno de las Sociedades. Ministerio de Economía y Hacienda: Madrid.

Olsen, W., V. Gash, L. Vandecasteele, H. Heuvelman and P. Walthery (2009), 'The gender pay gap in the UK 1995-2008,' Work Pensions and Labour Economics Group. WPEG 2009 Annual Conference. University of Nottingham.

Ortega, R. (2007), ‘Existe discriminación por género en salario y promoción en España?' Evidencia con el Panel de Hogares de la Unión Europea, 98, 1-26.

Pagán, R. (2007), 'Diferencias salariales entre el empleo a tiempo completo y parcial,' Revista de Economía Aplicada, 43(15), 5-47.

Palacio, J. I. and H. Simón (2002), 'Segregación laboral y diferencias salariales por sexo en España,' Estadística Española, 48(163), 493-524.

Palacio, J. I. and H. Simón (2006), 'Segregación laboral y diferencias salariales por razón de sexo en España,' Estadística Española, 48(163), 493-524.

Papapetrou, E. (2008), 'Evidence on gender wage differentials in Greece,' Economic Change and Restructuring, 41, 155-166.

Plan for Equal Opportunities for Men and Women [1997-2000] (1997). Ministerio de Trabajo y Asuntos Sociales. Instituto de la Mujer, Dirección General: Madrid, España.

Plantenga, J. and C. Remery (2006), 'The gender pay gap-origins and policy responses,' A Comparative Review of 30 European Countries, European Commission, Directorate-General for Employment, Utrecht School of Economics: Rotterdam, Holland.

Porto, N., I. Neira and M. E. Vázquez (2010), 'Perfil de la mujer directiva española,' Revista Universitaria de Ciencias del Trabajo, 11, 147-173.

Pucheta, M. C. and C. Narro (2014), 'La comisión de remuneraciones y las retribuciones de los consejeros,' Academia, Revista Latinoamericana de Administración, Forthcoming.

Renner, C., J. M. Rives and W. F. Bowling (2002), 'The significance of gender in explaining senior executive pay variations: an exploratory study,' Journal of Managerial Issues, 14(3), 331-345.

Rogelberg, S. G. and S. M. Rumery (1996), 'Gender diversity, team decision quality, time on task, and interpersonal cohesion,' Small Group Research, 27(1), 79-90. 
Rubery, J., D. Grimshaw and H. Figueiredo (2005), 'How to close the gender pay gap in Europe: towards the gender mainstreaming of pay policy,' Industrial Relations Journal, 36(3), 184-213.

Salas, V. (2002), 'El gobierno de la empresa,' Colección de Estudios Económicos de la Caixa, 2002, N²9, Barcelona.

Sánchez, G. and M. E. Lucas (2008), El nivel retributivo de los altos directivos en las empresas cotizadas españolas, Influencia del tamaño y composición del Consejo de Administración. Boletín Económico de ICE $\mathrm{N}^{\circ}$ 2938, del 16 al 31 de mayo de 2008.

Schwartz-Ziv, M. (2011), 'Are all welcome A-board: what do women directors bring to the table?’ 1-39, http://www.hks.harvard.edu/m-rcbg/Events/schwartz\%20ziv.pdf,.

Shin, T. (2012), 'The gender gap in executive compensation: the role of female directors and Chief Executive Officers,' The Annals of the American Academy of Political and Social Science, 639, 258-278.

Singh, V., S. Terjesen and S. Vinnicombe (2008), 'Newly appointed directors in the boardroom: how do women and men differ?' European Management Journal, 26(1), 48-58.

Simón, H. (2006), 'Diferencias salariales entre hombres y mujeres en España: una comparación internacional con datos emparejados empresa-trabajador,' Investigaciones Económicas, 30(1), 55-87.

Simón, H. (2009), 'La desigualdad salarial en España: una perspectiva internacional y temporal,' Investigaciones Económicas, 32(3), 439-471.

Simón, H., R. Ramos and E. Sanromá (2005), ‘ ¿Nadar a favor o contra la corriente? Cambios en la estructura salarial y diferencias salariales por género en España?’ Ponencia de las VI Jornadas de Economia Laboral.

Simón, H., R. Ramos and E. Sanromá (2008), 'Evolución de las diferencias salariales por razón de sexo,' Revista de Economía Aplicada, 48(16), 37-68.

Skalpe, O. (2007), 'The CEO gender pay gap in the tourism industry-Evidence from Norway,' Tourism Management, 28, 845-853.

Smith, N., V. Smith and M. Verne (2011), 'The gender pay gap in top corporate jobs in Denmark. Glass ceilings, sticky floors or both?' International Journal of Manpower, 32(2), 156-177.

Spanish Constitution (1978). Article 14. (BOE de 29 de diciembre de 1978). Madrid. España. Available at: http://www.boe.es/boe/dias/1978/12/29/pdfs/A29313-29424.pdf.

Spanish National Institute of Statistics (2012), Encuesta de Población Activa (EPA). Nota de Prensa.26 de octubre de 2012. Instituto Nacional de Estadística: Madrid, España. Available at: http://www.ine.es/daco/daco42/daco4211/epa0312.pdf.

Tenjo, J., R. Ribero and L. F. Bernat (2005), '), 'Evolución de las diferencias salariales por sexo en seis países de América Latina un intento de interpretación,' Documento CEDE (Centro de Estudios sobre Desarrollo Económico). Facultad de Economía: Universidad de los Andes, Bogotá.

Terjesen, S., R. Aguilera and R. Lorenz (2014), 'Legislating a woman's seat on the Board: institutional factors driving gender quotas for Boards of Directors,' Journal of Business Ethics, Forthcoming. doi: 10.1007/s10551-014-2083-1. 
Terjesen, S., R. Sealy and V. Singh (2009), 'Women directors on corporate boards: a review and research agenda,' Corporate Governance: An International Review, 17(3), 320-337.

Terjesen, S. and V. Singh (2008), 'Female presence on corporate boards: a multi-country study of environmental context,' Journal of Business Ethics, 83(1), 55-63.

Tharenou, P., S. Latimer and D. Conroy (1994), 'How to make it to the top? An examination of influences on women's and men's managerial advancement,' Academy of Management Journal, 37, 899-931.

The United Nations Report (2010), The World's Women 2010. Trends and Statistics. Department of Economic and Social Affairs: United Nations, New York, USA.

Ullibarri, M. (2003), 'Diferencias salariales entre los sectores público y privado por género, escolaridad y edad,' El trimestre Económico, 70(278), 233-252.

Unified Code of Corporate Governance (CUBG). (2006), Informe del grupo especial de trabajo sobre buen gobierno de las sociedades cotizadas, Comité Conthe: Madrid.

Van Pelt, T. (2013), 'The effect of board characteristics on dividend policy,' Working paper, Tilburg School of Economics and Management, Department of Finance. Tilburg University: The Netherlands, pp. 1-62.

Varela, R., J. M. Ocegueda, R. A. Castillo and G. Huber (2010), 'Determinantes de los ingresos salariales en México: una perspectiva de capital humano,' Región y Sociedad, 22(49), 117-141.

Vieito, J. P. and W. A. Khan (2012), 'Executive compensation and gender: S\&P 1500 listed firms,' Journal of Economics and Finance, 36(2), 371-399.

Vitaliano, D. F. (2009), 'Gender wage differences and human capital in the early twentieth century: the case of the paper box industry in New York,' Revista Económica Household, 7, 179-188.

Wellalage, N., F. Fauzi and G. Wang (2012), 'Corporate governance and cash dividend policy: evidence from Chinese IPOs,' Working Paper, 1-24.

Westphal, J. D. and L. P. Milton (2000), 'How experience and network ties affect the influence of demographic minorities on corporate boards,' Administrative Science Quarterly, 45(2), 366-398.

Wood, R. G., M. E. Corcoran and P. N. Courant (1993), 'Pay differences among the highly paid: the male-female earnings,' Journal of Labor Economics, 11(3), 417-441.

Workers' Statute Act (1980), Article 28. (BOE de 14 de marzo de 1980). Madrid. España. Available at: http://www.boe.es/boe/dias/1980/03/14/pdfs/A05799-05815.pdf.

Ye, K., R. Zhang and Z. Rezaee (2010), 'Does top executive gender diversity affect earnings quality? A large sample analysis of Chinese listed firms,' Advances in Accounting, 26(1), $47-54$.

Zelechowski, D. and D. Bilimoria (2004), 'Characteristics of women and men corporate inside directors in the US,' Corporate Governance: An International Review, 12(3), 337-342. 